One visitor too many: Assessing the impact of overtourism in established European urban destinations

\begin{tabular}{|r|l|}
\hline Journal: & International Journal of Tourism Cities \\
\hline Manuscript ID & IJTC-09-2019-0152.R1 \\
\hline Manuscript Type: & Research Article \\
\hline Keywords: & overtourism, quality of life, urban tourism, Europe, composite indicator \\
\hline
\end{tabular}




\title{
One visitor too many: Assessing the degree of overtourism in established European urban destinations
}

\begin{abstract}
Purpose: The aim of this study is to provide a series of indicators to determine the limits to urban tourism growth, tourism gentrification and overtourism. The study addresses overtourism within the frame of urban liveability through a proxy analysis of tourism-relevant indicators for major European tourist cities.
\end{abstract}

Design/methodology/approach: Based on the various indicators, a composite overtourism indicator is derived. The following dimensions are considered for the composite indicator: a) total number of overnight stays per relevant tourist area in $\mathrm{km} 2$; b) number of museum visitors per population; 3 ) average annual change in total nights between 2009 and 2017 and 4) foreign nights per population.

Findings: Based on the results, Venice is the city with the highest degree of overtourism, followed by Florence, Seville and Lisbon. The remaining cities have a lower than average overtourism potential as indicated by the negative $z$ score.

Research limitations/implications: This study and the composite overtourism indicator are only a starting point that can lead to further research in the field. Recommendations for further studies include the assessment of visitor flow and overtourism at different times of the year and to expand the study to other European urban destinations.

Practical implications: The paper suggests that policymakers should use these indicators when managing urban tourism development and monitoring visitor growth. Furthermore, they can be a starting point from which to assess the impact of tourism on the quality of life of local residents.

Social implications: This study provides a starting point from which to assess the causes for social unrest tied to overtourism. If the city under study is found to have a lower than average overtourism potential, this indicates that there may be other social or psychological issues at play apart from sheer overcrowding.

Originality/value: To date, there has been no composite indicator that considered the different numerical aspects of overtourism altogether. This study provides a set of key indicators and a composite overtourism indicator to provide a preliminary appraisal of overtourism as a demand-side phenomenon with evidence from a range of established European urban destinations. 


\section{Introduction}

Urban destinations are a major component of international and domestic tourism across Europe. According to the Mastercard's 2018 Global Destination Cities Index report (2018), two of the top three urban tourism destinations worldwide in terms of number of international overnight stays are in Europe, with London, Paris and Palma de Mallorca ranking in the top ten for overall international tourist expenditure. In terms of visitor spending, the City Travel \& Tourism Impact 2018 report suggests that inbound visitor spending in London in 2017 was approximately USD\$16.7 billion (WTTC, 2018). However, it would appear that leading European tourism cities have reached saturation point, with cities from Asia and the Pacific outperforming in terms of tourism market size and international overnight stays (MasterCard, 2018; WTTC, 2018). This is further evident in the reliance on international tourist spending in cities like Amsterdam, Barcelona, Budapest, Dubrovnik, Dublin, Prague and Venice, with more than $87 \%$ of total receipts, on average, coming from foreign visitors (WTTC, 2018).

"Capital cities represent a special case of urban tourism" (Hall, 2005: 219), yet there are limited data and conceptual frameworks addressing the phenomenon from a comparative perspective (Maitland, 2009). Given the cultural and economic relevance of capital cities and their importance in terms of tourism economy and market shares, the current fragmentation of research is unexpected. "National capitals then deserve study in their own right, to help gain a more nuanced understanding of cities and tourism" (Maitland, 2009: 3). Focusing on regional capitals in Europe, the shift to leisure and tourism has led to cities increasingly specializing in the visitor economy, with subsequent increases in terms of intra-urban market competitiveness and transformation of the local economy (Garcia, 2004; González, 2011; Souliotis, 2013). In addition, the liberalization of air transport in Europe has contributed to the rise of short-breaks in urban destinations (Ejarque, 2003; Hall \& Page, 2014), while the more recent rise of the sharing economy and social media has diversified the provision of leisure and hospitality services in European cities (Oltermam, 2016; Oskam, 2019; Zervas, Proserpio \& Byers, 2017), with substantial repercussions both in terms of length of stay and visitor expenditure. As the 2017-2020 Tourism Strategy for Barcelona puts it, "cities are increasingly playing host to short-term or very short-term residential stays and this represents a challenge for their management" (Ajuntament de Barcelona, 2017: 30).

Arguably, the introduction of the European Statistical Office (Eurostat) has helped in the harmonization of statistical methods and collection of data at metropolitan level. As Global Benchmarking for City Tourism Measurement (UNWTO, 2014) states, the development of cohesive 
subnational statistical frameworks at the regional and local level is a necessary condition for the collection and comparative analysis of urban tourism in different cities. Frameworks like the European Tourism Indicators System (ETIS), the European Cities Marketing (ECM) Benchmarking Report and TourMIS have been developed to benchmark European key urban destinations and "provide the knowledge necessary for stakeholders to make better-informed decisions" (UNWTO, 2014: 6). In this study, a new approach is developed to ascertain the impact of tourism on key urban tourist areas and provide relevant stakeholders with a composite overtourism indicator.

Urban tourism in Europe is increasing exponentially. Data from 2017 suggests that visiting cities has become more popular than coastal tourism among Europeans, with a $100 \%$ increase in city trips since 2007 and Europe leading the urban tourism market, with nearly $60 \%$ of overall international city trips (IPK International \& ITB Berlin, 2018). Currently, cities design and implement destination strategies oriented towards attracting more visitors and meeting the needs and expectations of current and prospective users (UNWTO, 2012). Nevertheless, there are heightening concerns on the socioeconomic and socio-cultural implications for existing residents (Gotham, 2005; Harvey, 2005; Yanes, 2019). As Amore (2019: 3) notes, "the increasing volume of visitor nights, expenditure and related investments towards urban tourism has brought tensions between tourists and residents". European urban destinations, in particular, have fallen short in the redistribution of services and facilities between residents and tourists (Milano, Cheer, \& Novelli, 2019). This is further emphasized in the recent report by the European Parliament (2018: 15) on overtourism and poor destination planning causing "significant damage to landscapes, seascapes, air and water quality, as well as the living conditions of residents".

The aim of this paper is to provide a series of indicators to determine the limits to urban tourism growth, tourism gentrification and overtourism. Indicators have been used in a recent study in Venice (Visentin \& Bertocchi, 2019) and in the European Parliament report (2018), yet their relevance in the study of overtourism can be disputed from a phenomenological perspective. The proposed paper seeks to address the phenomenon of overtourism and urban liveability through a proxy analysis of tourism-relevant indicators. The paper develops a composite overtourism indicator based on different data sources for the 15 tourist cities in Europe which are most frequently discussed on social media as being vulnerable to overtourism.

These include foreign arrivals and number of museum visitors per inhabitant, overnight stays within the surface area of the main tourist attractions and their growth rate. The paper suggests that 
policymakers should regard these indicators when framing urban tourism development and monitoring visitor growth as well as the impact of tourism on the quality of life of urban residents.

\section{On urban tourism and overtourism}

The management of tourism-related activities and resources is a central feature of contemporary planning and policymaking (Hall, 2008) and reflects nearly thirty years of debate on the limits to growth and sustainable development in tourism (Getz, 1992; Hall \& Amore, 2016; Weaver, 2000). Urban tourism is no exception to this trend. Researchers have, since the 1990s, been closely monitoring aspects such as tourist arrivals, the number of nights spent, the relevance of the tourist economy to the city and the commodification of urban spaces (Amore, 2019; Law, 2002; Judd, 1999). In fact, the introduction of the concept of carrying capacity in the study of heritage cities like Bruges, Florence and Venice precedes the current debate on overtourism by nearly twenty years (van der Borg, Costa \& Gotti, 1996). In the case of Venice, the recommendation was for a cap on tourist arrivals in the range of 20,000 per day, excluding excursionists (van der Borg, 2001). However, the response from local authorities, to date, has been to ignore this advice, with subsequent repercussions in terms of liveability and tourist pressure for the local residents (Seraphin, Sheeran \& Pilato, 2018).

Over the last decade, researchers have acknowledged the importance of perception among tourism stakeholders shifting away from merely determining a maximum number of users (Coccossis \& Mexa, 2004). This has resulted in a shift from carrying capacity to limits of acceptable change (LAC), with the latter being defined as "a management tool for setting limits or managing tourism are assessing carrying capacity, or developing indicators for tourism optimization" (Dodds, 2012: 56). For example, researchers in urban tourism recently introduced LAC as an analytical technique in established European urban destinations. In particular, the work by Janusz, Six \& Vanneste (2017: 128) in Bruges, Belgium provides valuable insights into resident perceptions towards tourism development in the city and advises local authorities "to design policies to match the needs of residents, build a tourismresilient community and, as a consequence, minimize the risk of potential conflicts."

Notwithstanding the importance of indicators and monitoring of tourism in cities, the interpretation, acknowledgement and implications for planning and policy is not as straightforward. As Oskam (2019: 86) argues, "it is impossible to objectively establish when tourist pressure becomes excessive [...] as the acceptance of visitors depends on different factors such as cultural affinity and perceived economic benefits for residents". Moreover, the lobbying of the private sector is likely to influence pro-growth approaches to tourism development at the expense of sound sustainable strategies 
(Farmaki, Altinay, Botterill \& Hilke, 2015; Hall, 1998). Oftentimes anecdotal evidence sheds light on residents' limits to acceptable change more than reports and statistics. For example, the closure of the last floating florist in Amsterdam due to tourists crowding out regular customers (Boffey, 2019a) or 'Airbnb syndrome' in Reykjavik (Mermet, 2017, emphasis in the original) are two of the many instances of degenerative outcomes as a result of tourism-led development in cities around the world.

There are different explanations as to why the response from policymakers and the tourism industry has to date been inadequate. On the one hand, tourism industry stakeholders tend to regard tourist use of cities and carrying capacity as neither important nor unimportant issues in urban tourism (Edwards, Griffin \& Hayllar, 2008). On the other hand, the tendency among DMOs is still that of promoting places whilst parroting the rhetoric of economic development (Pike \& Page, 2014). Arguably, "very few DMOs have either the mandate or resources to effectively manage their destination" (Pike \& Page, 2014: 204), particularly in cities (Page \& Hall, 2003). The recent calls for the redefinition of DMOs' role in the management of destinations (Hall \& Veer, 2016; Volgger \& Pechlaner, 2014) reflect a growing awareness among scholars in regard to the need to monitor visitor arrivals in mature and overcrowded destinations. The role of urban DMOs is already under scrutiny in established destinations, as can be seen in the recent tourism strategies in Barcelona (Ajuntament de Barcelona, 2017), Amsterdam (Boffey, 2019b) and Prague (SmartPrague, 2017).

The rise of overtourism is a reflection of "a relatively recent phenomenon in terms of what is perceived as too many tourist visitors and too much tourism-related development in specific destinations" (Butler, 2019: 76). The UNWTO (2018: 4) defines overtourism as "the impact of tourism on a destination, or parts thereof, that excessively influences perceived quality of life of citizens and/or quality of visitors experiences in a negative way." Over the last several years, scholars have begun to address this phenomenon in relation to cities, historic towns, natural sites and festivals (Adie, 2019; Muler Gonzalez, Coromina \& Gali, 2018; Seraphin et al., 2018; Smith, Sviza \& Olt, 2019). However, it should be noted that the problem of overcrowded sites and places is as old as tourism research itself, with different sources stressing the correlation between long-established tourism planning and management models and current issues with overtourism (Dodds \& Butler, 2019). Not surprisingly, Dredge (2017: n.p.) argues that "coining the term "overtourism" [means] simply resetting the clock on well-established debates".

Such "renewed interest in the adverse impacts of tourism" (Milano, Novelli \& Cheer, 2019: 355) is currently contributing in a redefinition of concepts and models of tourism development, sustainability and host-guest relationships in urban contexts. Evidence from Budapest, Hungary, shows that both 
residents and tourist are increasingly aware of the steady decrease of urban liveability and tourist experience in the city (Smith et al., 2019). In another example, findings from Dubrovnik, Croatia, illustrate how authorities are currently addressing overtourism through the introduction of visitor caps and daily cruise passenger arrivals (Panayiotopoulos \& Pisano, 2019). A recent study conducted in Munich, Germany, analyses the perceptions and evaluation of different forms of urban tourism consumption in the city and their impact on the liveability of residents wherein nearly half of the respondents were of the opinion that "there are already too many tourist overnight stays per year in the city" (Namberger et al., 2019, 461). Overall, these studies highlight the importance of both understanding and developing measures to combat overtourism in urban environments.

To date, research on overtourism in urban destinations is conjunctural and predominantly focuses on European cities. A good extent of the emerging body of knowledge stresses the perceptions of residents towards tourists and the repercussions at destination level in terms of touristification and loss of authenticity (Rickly, 2019), overcrowding, decreased quality of life and spatial displacement (Milano et al., 2019). On the other hand, Wall (2019: 28) argues that "issues of overtourism are primarily, but not exclusively, challenges for destinations" that can be addressed by looking at the concentration of visitors around attractions. In his view, it is "the search for such number[s] [...] empowers experts to inform decision makers of how many is too many" (Wall, 2019: 34).

Given the emerging definitions and applications of overtourism in the literature, it can be concluded that there are no prescriptive methods and models to define and measure the phenomenon. It is in this stage of knowledge creation that new approaches and indicators can be tested. Arguably, this resembles the third-order change in policy making, "where experiment and perceived policy failure has resulted in discrepancies or inconsistencies appearing which cannot be explained within the existing paradigm" (Greener, 2001: 135). In order to aid in the development of new approaches, the remainder of this paper develops and applies a composite overtourism indicator for established European urban destinations.

\section{Research design}

This study develops a composite indicator for overtourism for selected European cities which includes various aspects, such as urban tourism dynamics and the current volume of visitation. The novelty of the approach is that the number of overnight stays is measured in relation to the area of the relevant tourist zone. Several individual indicators are calculated and applied to the 15 European cities who have the highest number of related tweets with the hashtag" overtourism" on Twitter: Amsterdam, 
Barcelona, Berlin, Copenhagen, Edinburgh, Florence, Lisbon, London, Madrid, Paris, Prague, Rome, Seville, Venice and Vienna.

The number of arrivals or overnight stays per inhabitant is the standard indicator that is often used for policy development. However, this indicator, which is based on the number of inhabitants of a city, can be misleading for various reasons. One is that urban tourists and day-trippers tend to cluster along with other city users in the central city area which is home to cultural amenities, universities, government agencies and the headquarters of multinationals. Another relates to the phenomenon of urban tourism off the beaten track, which, while acknowledge, is still relatively limited, occurring in only a few cities (Maitland \& Newman, 2014). Additionally, few visitors visit the suburbs and residential areas of major European cities, and accommodation tends to be clustered within the city centre and surrounding neighbourhoods or in proximity to key attractions and amenities (Pearce, 1998). Furthermore, the average length of stay in the cities under consideration is between 2 and 2.5 days, which results in tourists and visitors concentrating on the main attractions in the city centre ${ }^{1}$.

Another controversial indicator often used for policy-making is that of urban tourism density where calculating the ratio of number of visitors to local population can lead to a low proportion of visitors per inhabitant in larger metropolitan areas such as London, Paris and Madrid. Arguably, the solution would be to use the resident population in city centres as denominator. However, this approach is not adequate for spatially distinct and low-density city centres like Venice. Moreover, the contemporary city encompasses residents, commuters, city users, tourists and metropolitan businessmen that inflate the number of people on a day-to-day basis (Costa \& Martinotti, 2003). This study therefore suggests that neither the area nor the total population are adequate to define the relevant space in which tourists are located.

\section{Composite overtourism indicator}

This study deploys a demand-side appraisal of overtourism and overcrowding in focal urban tourism precincts, here defined as "a distinctive geographic area within a larger urban area, characterised by a concentration of tourist-related land uses, activities and visitations" (Hayllar \& Griffin, 2005: 517). Rather than focusing on the negative perceptions among residents and visitors emphasized in the literature, this study proposes to look at key visitor indicators and the density of tourism activity in relation to surface, density and resident population.

\footnotetext{
${ }^{1}$ Average length of stay is calculated as a ratio of nights spent and arrivals (Source Accommodation statistics of the national statistical offices).
} 
For each of the 15 European cities, the composite indicator includes the surface of the city centre, as this overlaps with the aforementioned urban tourist space (Amore, 2019; Getz, 1993; Pearce, 1998). Moreover, it includes the narrowly defined population, the total overnight stays, the foreign overnight stays, the number of museum visitors and the growth of total overnight stays between 2009 and 2017 . The key indicators are the number of overnight guests and the number of museum visitors which measure the level of tourism pressure, while the growth rate of overnight stays reflects the dynamics. This approach highlights the rise of cultural tourism in European cities over the last decade (Du Cros and McKercher, 2014Law, 2002;) and the growing importance of large cities in the national economies.

Urban tourism precincts often consist of a combination of attractions and amenities, "especially the dominance of historic buildings" (Hayllar and Griffin, 2005: 517). It is in these key city areas the phenomenon of overtourism threatens urban liveability, with episodes of anti-tourism protests in cities like Amsterdam, Athens, Barcelona and Venice (Boffey, 2019b; Rickly, 2019). Therefore, a valuable indicator is that of visitor pressure in such urban tourism precincts. This is measured through the inclusion of the surface area of the top 10 attractions listed on TripAdvisor as well as the surrounding space. As the figures in the appendix illustrate, Barcelona, Belin, Copenhagen and Lisbon have the largest areas based on the top 10 attractions measured in square kilometres, while Amsterdam, Florence and Seville have the lowest.

In addition, this study considers the long-term growth rate of overnight stays to be relevant for measuring the potential extent of overtourism and the steady increase of urban tourism over the last several years. Particularly in European cities, the supply of cultural attractions, amenities and leisure facilities has not increased, yet the number of visitors to the observed cities has grown at a faster rate than at national level. Therefore, it is important to consider the recent dynamics of urban tourism in Europe. In this study, the average annual growth rate of overnight stays for the years 2009 and 2017 is used to obtain a measure of the increase of tourism in the observed cities.

Finally, the number of museum visitors per inhabitant is used as a sub-indicator of overtourism. This study suggests that museum visitors are a better indicator to ascertain overtourism than the total number of arrivals or overnight stays. The latter, in fact, includes also city users and metropolitan businessmen (Costa \& Martinotti, 2003) and downplays the relevance of VFR tourism in major cities. The number of visitors to museums, instead, allows for the identification of visitors and tourists that purposefully come to visit key urban tourism attraction and cultural anchors.

The resulting dimensions help define four indicators for the purposes of this study: 
(i) total number of overnight stays per relevant tourist area in $\mathrm{km}^{2}$;

(ii) number of museum visitors per population (narrowly defined);

(iii) Average annual change (\%) in total nights between 2009 and 2017;

(iv) Foreign nights per population (narrowly defined).

The indicators are calculated for the year 2017. A narrow definition is used for the population, focusing on the number of inhabitants in the city rather than in the larger urban agglomeration. For example, the population of the city of Paris is about 2.1 million people, compared to the metropolitan area of Paris with 12 million. Table 1 below shows the correlation coefficients of the sub-indicators. Overall, the change in total overnight stays and total overnight stays are significantly negatively correlated indicating that cities with a large number of overnight stays have a lower growth potential. The negative correlation demonstrates that the growth rate provides complementary information on the degree of overtourism that is not captured in the level variable. The total number of museum visitors per resident and foreign overnight stays per resident are highly correlated (with a correlation coefficient of 0.92). It can be argued that this indicates a high degree of overlap between the two indicators. However, we have decided to maintain both indicators. The reason for this is that overnight stays or arrivals per inhabitant are the standard indicator of overtourism used by policy makers. Museum visitors per inhabitant, instead, measures the tourist threat to cultural heritage.

>>Insert Table 1 here $<<$

\section{Findings}

Table 2 shows the four indicators for overtourism as identified in this study. According to the total overnight stays per surface, Florence is the most overcrowded city in the group of 15 selected cities. In 2017, the ratio of total overnight stays per square kilometre accounted to 11.2 , a value that is in sharp contrast with other key European heritage cities like Edinburgh, Sevilla and Venice. This is mainly due to the relatively small size of the historic city centre of Florence and the proximity of the ten main cultural attractions listed on TripAdvisor. In particular, the area stretching from Palazzo Vecchio, the Uffizi museum and the iconic Ponte Vecchio are located within a radius of 300 meter from each other, covering a surface of 0.86 square kilometres. The second city by total overnight stays per surface was London with a ratio of 9.8. Unlike with Florence, the top attractions in London are scattered between the City and the boroughs of Westminster and Southwark, with the total tourist city surface being 8.5 square kilometres. Moreover, London is the leading tourist destination in the United Kingdom, with nearly double the international tourism nights in comparison with the other top-20 urban destinations 
in the country (VisitBritain, 2018). The third city in this special ranking is Paris, which presents very similar urban tourism characteristics with London, but has a significantly lower ratio of overnight stays per square kilometre (5.5). At the bottom of the table, we have Copenhagen and Lisbon, with a total overnight per surface indicator of 0.7 and 0.3 respectively. Particularly with the case of Lisbon, the area comprising the main attractions is significantly bigger than those of the other observed cities $\left(42.5 \mathrm{~km}^{2}\right)$, with the riverfront home to key attractions like the Parque das Nações, the Terreiro do Paço and the Belém heritage area.

\section{> Insert Table 2 here $<<$}

Focusing on the number of museum visitors per inhabitant, Edinburgh, Florence and Venice are ranked highest among the observed cities, which reflects their profile as heritage cities and secondary regional capitals. Venice scores the highest in terms of ratio of museum visitors relative to the local population, with 83 museum visitors per resident. Florence has the second highest, albeit with a significantly lower ratio of 38 , while Edinburgh ranks third with 14 . It is important to observe that none of the museums in these cities are among the leading ten museums in Europe based on attendance. The Uffizi only ranks fourteenth with 2.3 million visits in 2018, while the National Museum of Scotland based in the city centre recorded 2.2 million visits in the same year (TEA \& AECOM, 2019). Moreover, these three cities have a comparatively smaller resident population that those of the other shortlisted cities, thus contributing in part to the inflated indicator. Conversely, Barcelona, Paris, Madrid, Seville and Prague have the lowest number of museum visitors in relation to the local population with ratios ranging from 3.9 to 2.4. In particular, Paris and Madrid are home to three of the top-ten museums in Europe for number of visits in 2018 and totalled 26 million museum visits combined in the same year (TEA \& AECOM, 2019). In general, the number of museum visitors per inhabitant shows a higher degree of variation than the number of overnight stays per inhabitant as measured by the standard deviation.

Focusing on the third indicator, evidence suggests that the average growth rate of overnight stays between 2009-17 ranged from 0.7 per cent in London to 9.6 per cent in Lisbon. This indicator reflects the predominance of London as long-established key urban tourist destination in the United Kingdom and worldwide (MasterCard, 2018; VisitBritain, 2018; WTTC, 2018). On the other hand, it underpins the spike in tourist arrivals registered in Lisbon, particularly in relation to the escalation of short-term rentals since 2012 (Cócola-Gant \& Gago, 2019; Ferreira, Ramos \& Lahr, 2019; Tulumello, 2016). The average growth rate for the observed cities is 5 per cent, which is well above the average growth rate of arrivals or overnight stays registered in Europe in the same period. In particular, the growth rate of 
overnight stays between 2012-2017 in the EU-28 countries was 4 per cent per year on average. The findings from the observed cities also underpin the rise of urban tourism in Europe: while overnight stays in the EU-28 cities increased by 7 per cent per year, rural areas stagnated ( 0.4 per cent) (see Table 1 in the Appendix). Overall, the findings from this work and the recent trends observed in Europe reflect the observed perceptions of overtourism over the last years addressed in the literature.

The final indicator concerns the number of foreign overnight stays per inhabitant (narrow definition) for the year 2017. This indicator shows the highest dispersion of all indicators as measured by the standard deviation, with Venice (124.4) being the first among the observed cities. This specific indicator underpins the chronic imbalance between tourists and resident population, which has recently led to the expression "Venice Syndrome" in the literature (Milano, 2017). Lisbon ranks second in this specific list, with a ratio of 17.3. This finding reflects the predominance of international tourists in the Portuguese capital and the relatively low inclination towards short breaks among domestic tourists in the country (Amore, Falk \& Adie, 2019). Conversely, the indicator for Amsterdam (16) is at odds with the inclination among Dutch tourists towards multiple short-breaks during the year (Amore et al, 2019), but reinforces the disproportion between the number of tourists and the residents in the Amsterdam inner city area observed in other studies (Gerritsma, 2019).

In light of the four aforementioned indicators, a composite overtourism indicator is developed. As the different indicators are distinctly scaled, each variable is standardised by the z-Score normalisation. The basic z-Score formula for a sample is:

- $\mathrm{z}=(\mathrm{x}-\mathrm{xmean}) / \mathrm{s}: \mathrm{z}$ standardised overtourism indicator;

- $\mathrm{x}$ : overtourism indicator;

- xmean: mean of the overtourism indicator for the 15 cities;

- s: standard deviation of the overtourism indicator for the 15 cities.

For each indicator, the mean value of the sample is subtracted and the resulting difference divided by the standard deviation. The composite indicator is constructed as the unweighted mean of the four indicators. The mean of the composite indicator is zero with a standard deviation of one per definition.

Table 3 below reports the results of the composite overtourism indicator. Based on the results, Venice is the city with the highest degree of overtourism and the only city of the 15 under study with a score higher than 1 (1.4). This is mainly due to it having the highest number of foreign overnight stays per inhabitant and the highest number of museum visitors per inhabitant. Florence ranks second with a score of 0.8 , while Seville and Lisbon are ranked third and fourth, with a score of 0.3 and 0.2 
respectively. This is predominantly the result of the high growth in overnight stays in these cities over the observed period. The remaining cities have a lower than average overtourism potential as indicated by the negative $z$ score.

>> Insert Table 3 here $<<$

Robustness checks have been conducted. First, we use different weights and assign lower weight to the two indicators that are highly correlated (number of museum visitors per resident and foreign overnight stays per resident because of the high correlation). Again, the results show that Venice is the city that has the highest potential of overtourism, and the ranking does not differ much. Second, the long-term growth rate of overnight stays is calculated for shorter periods. Again, the overtourism ranking is quite stable (results are available upon request).

\section{Discussion and conclusions}

The results show that Venice is the city with the highest degree of overtourism followed by Florence, Seville, Lisbon and Amsterdam. The findings of this study underpin anecdotal and empirical evidence from current literature (Amore, 2019; Milano et al, 2019; Seraphin et al, 2018; Tulumello, 2016). The inclusion of Venice at the top of this list merely affirms recent community unrest in relation to tourism and a long-standing history of prioritization of tourism growth over community welfare (Seraphin et al., 2018; van der Borg, 2001). However, what is of particular interest to note is that many of the studied cities have a lower than average overtourism potential, which contrasts with the extensive media coverage surrounding the overtourism problem that each city is facing. For example, Edinburgh, who holds the penultimate position in the ranking, has frequently been discussed in the media as tensions grew between local residents and the city council. The city has even gone so far as to approve the implementation of the UK's first tourist tax, charging $f 2$ per night for all accommodation types. Thus, this study appears to support Oksam (2019) by highlighting that a sheer objective, numbers driven approach is insufficient in the discussion of overtourism. In order to truly understand the level of acceptable tourism, all city-users' (residents, commuters, tourists, day visitors) opinions need to be considered in the planning process. However, similarly to past research on carrying capacity, this line between acceptable and overtourism may be unknowable until after it has been crossed.

Discussions on the degree of overtourism in European cities are at a turning point among academic and political institutions (European Parliament, 2018; Milano et al., 2019). Measuring the degree of overtourism is essential for urban planners, city managers and DMOs. However, the proliferation of 
studies and approaches over the last several years tends to overlook the complexity of longitudinal studies and the need for exhaustive indicators to support decision making and management of tourism in congested urban areas. To date, there has been no composite indicator that considered the different numerical aspects of overtourism in combination with each other. This study, then, provides a set of key indicators and a composite overtourism indicator to provide a preliminary appraisal of overtourism as a demand-side phenomenon with evidence from a range of established European urban destinations. From a management and policy perspective, this indicator provides a starting point from which to begin discussions around tourism in urban areas of Europe. In particular, it can function as a justification for opening up planning processes to local residents in order to understand whether complaints of overtourism are related to dissatisfaction with tourism or with city spaces and services as a whole.

This study and the composite overtourism indicator are only a starting point that can lead to further research in the field. For example, it is important to expand the application of the composite overtourism indicator to other major European urban destinations, including those addressed in the literature (e.g. Budapest and Munich) (Namberger et al., 2019; Smith et al., 2019), those where tourism is becoming a crucial element of the urban economy (e.g. Milan) as well as established urban destinations that are currently overlooked in the literature (e.g. Athens, Istanbul and Krakow). Additionally, this composite indicator would be ideal to ascertain the visitor flow in cities at different times and seasons of the year in order to ascertain the impact of congestion in the summer months, as, arguably, forms of niche urban tourism are likely to occur in lower season or in the shoulder months of the year, while hallmark events can directly impact on the type of tourist and city user (e.g. Oktoberfest in Munich). It would also be useful to utilize the composite overtourism indicator to provide a longitudinal appraisal of the phenomenon for policy purposes. However, given the apparent disconnect between perceptions of overtourism as expressed in the media and the indicator's findings, it would be beneficial to incorporate it into a mixed methods approach which allowed for the inclusion of the city users' thoughts on the topic. This would allow for more effective and sensitive urban tourism planning.

\section{References}

Adie, B. A. (2019), World Heritage and Tourism: Marketing and Management, Routledge, Abingdon. 
Ajuntament de Barcelona (2017), Barcelona Tourism for 2020: A Collective Strategy for Urban Tourism, Ajuntament de Barcelona, Barcelona.

Amore, A. (2019), Tourism and Urban Regeneration: Processes Compressed in Time and Space, Routledge, Abingdon.

Amore, A., Falk, M. and Adie, B A. (2019), "Modelling the characteristics of European short-stay trippers", paper presented at the Between Overtourism and Undertourism: Implications and Crisis Management Strategies, 26-29 June, Lecce, Italy.

Boffey, D. (2019a, 16 April), "Amsterdam's last floating florist closes, blaming tourists", The Guardian, available at: https://www.theguardian.com/world/2019/apr/16/amsterdams-last-floatingflorist-closes-blaming-rowdy-tourists (accessed May 10, 2019).

Boffey, D. (2019b, 6 May), "'We must act now': Netherlands tries to control tourism boom", The Guardian, available at: https://www.theguardian.com/world/2019/may/06/we-must-actnow-netherlands-tries-to-control-tourism-boom (accessed August 19, 2019).

Butler, R. W. (2019), "Overtourism and the Tourism Area Life Cycle", in Dodds, R. and Butler, R. W. (Eds.), Overtourism: Issues, Realities and Solutions, De Gruyter, Berlin, pp. 76-89.

Coccossis, H. and Mexa, A. (2004), The Challenge of Tourism Carrying Capacity Assessment. Theory and Practice, Ashgate Publishing Limited, Aldershot.

Cócola-Gant, A. and Gago, A. (2019), “Airbnb, buy-to-let investment and tourism-driven displacement: A case study in Lisbon", Environment and Planning A: Economy and Space, https://doi.org/10.1177/0308518X19869012.

Costa, N. and Martinotti, G. (2003), "Sociological theories of tourism and regulation theory", in Hoffman M, Fainstein, S. S. and Judd, D. R. (Eds.), Cities and Visitors: Regulating People, Markets, and City Space, Blackwell Publishing, Oxford, pp.53-71.

Dodds, R (2012), "Sustainable tourism: a hope or a necessity? The case of Tofino, British Columbia, Canada", Journal of Sustainable Development, Vol. 5 No. 5, pp. 54-64.

Dodds, R. and Butler, R. W. (Eds.), Overtourism: Issues, Realities and Solutions, De Gruyter, Berlin. 
Dredge, D. (2017), "Overtourism: Old wine in new bottles?", available at https://www.linkedin.com/pulse/overtourism-old-wine-new-bottles-dianne-dredge (accessed 10 August 2019).

Du Cros, H. and McKercher, B. (2014), Cultural Tourism, Routledge, Abingdon.

Edwards, D., Griffin, T. and Hayllar, B. (2008), "Urban tourism research: Developing an agenda”, Annals of Tourism Research, Vol 35 No 4, pp. 1032-1052.

Ejarque, J. (2003), La Destinazione Turistica di Successo: Marketing and Management, Hoepli, Milan.

European Parliament (2018), Research for TRAN Committee -Overtourism: Impact and Possible Policy Responses, European Parliament, Strasbourg.

Farmaki, A., Altinay, L., Botterill, D. and Hilke, S. (2015), "Politics and sustainable tourism: The case of Cyprus", Tourism Management, Vol. 47, pp. 178-190.

Ferreira, J. P., Ramos, P. N., and Lahr, M. L. (2019). The rise of the sharing economy: Guesthouse boom and the crowding-out effects of tourism in Lisbon. Tourism Economics, https://doi.org/10.1177/1354816619839849.

Garcia, B. (2004), "Cultural policy and urban regeneration in Western European cities: lessons from experience, prospects for the future", Local Economy, Vol. 19 No 4, pp. 312-326.

Gerritsma, R. (2019), “Overcrowded Amsterdam: Striving for a balance between trade, tolerance and tourism", in Milano, C., Cheer, J. M. and Novelli, M. (Eds.), Overtourism: Excesses, Discontents and Measures in Travel and Tourism, CABI, Wallingford, pp. 125-147.

Getz, D. (1992), "Tourism planning and destination life cycle”, Annals of Tourism Research, Vol. 19 No 4, pp. 752-770.

Getz, D. (1993), "Planning for tourism business districts", Annals of Tourism Research, Vol. 20 No. 3, pp. 583-600.

González, S. (2011), “Bilbao and Barcelona 'in motion'. How urban regeneration 'models' travel and mutate in the global flows of policy tourism", Urban Studies, Vol. 48 No 7, pp.1397-1418. 
Gotham, K. F. (2005), “Tourism gentrification: The case of New Orleans' Vieux Carre (French Quarter)", Urban Studies, Vol. 42 No 7, pp. 1099-1121.

Greener, I. (2001), "Social learning and macroeconomic policy in Britain", Journal of Public Policy, Vol. 21 No 2, pp, 133-152.

Hall, C. M. (1998), "The politics of decision making and top-down planning: Darling Harbour, Sydney", in Tyler, D., Guerrier, Y. and Robertson, M. (Eds.), Managing Tourism in Cities: Policy, Process and Practice, John Wiley \& Sons, Chichester, pp. 9-24.

Hall, C. M. (2005), Tourism: Rethinking the Social Science of Mobility, Prentice Hall, Harlow.

Hall, C. M. (2008), Tourism Planning: Policies, Processes and Relationships (2nd ed.), Prentice Hall, Harlow.

Hall, C. M. and Amore, A. (2016), "Turismo, sostenibilità e crescita verde: Green Economy o una semplice pennellata di verde?", in Pecoraro Scanio, A. (Ed.), Turismo Sostenibile. Retorica e Pratiche, Aracne Editrice, Rome, pp. 145-188.

Hall, C. M. and Page, S. J. (2014), The Geography of Tourism and Recreation: Environment, Place and Space, Routledge, Abingdon.

Hall, C. M. and Veer, E. (2016), "The DMO is dead. Long live the DMO (or, why DMO managers don't care about post-structuralism)", Tourism Recreation Research, Vol. 41 No 3, pp. 354-357.

Harvey, D. (2005), Spaces of Neoliberalization: Towards a Theory of Uneven Geographical Development, Franz Steiner Verlag, Stuttgart.

Hayllar, B. \& Griffin, T. (2005), "The precinct experience: A phenomenological approach", Tourism Management, Vol. 26 No 4, pp. 517-528.

IPK International and ITB Berlin (2018), "World Travel Trends 2018/2019. What are the Travel Trends to Look for?", available at: https://www.itbkongress.de/media/itbk/itbk dl all/ITB 2019 WTTR Factsheets ALLE Web 4.pdf (accessed July 30, 2019). 
Janusz, K., Six, S. and Vanneste, D. (2017), "Building tourism-resilient communities by incorporating residents' perceptions? A photo-elicitation study of tourism development in Bruges", Journal of Tourism Futures, Vol. 3 No 2, pp. 127-143.

Judd, D. R. (1999), "Constructing the tourist bubble", in Judd, D. R. and Fainstein, S. S. (Eds.), The Tourist City, Yale University Press, New Haven, CT, pp. 35-53.

Law, C. M. (2002), Urban Tourism: The Visitor Economy and the Growth of Large Cities, Cengage Learning Emea, New York, NY.

Maitland, R. (2009), "Introduction: National Capitals and City Tourism", in Maitland R. and Ritchie, B. W. (Eds.), City Tourism: National Capital Perspectives, CABI, Wallingford, pp. 1-13.

Maitland, R. and Newman,P. (Eds.) (2014), World Tourism Cities: Developing Tourism Off the Beaten Track, Routledge, Abingdon

Mermet, A.-C. (2017), "Airbnb and tourism gentrification: Critical insights from the exploratory analysis of the 'Airbnb syndrome' in Reykjavik", in Gravari-Barbas, M. and Guinand, S. (Eds.), Tourism and Gentrification in Contemporary Metropolises, Routledge, Abingdon, pp. 53-75.

Milano, C. (2017), Overtourism and Tourismphobia; Global Trends and Local Context, Ostelea School of Tourism and Hospitality, Barcelona.

Milano, C., Cheer, J. M. and Novelli, M. (Eds.) (2019), Overtourism: Excesses, Discontents and Measures in Travel and Tourism, $\mathrm{CABI}$, Wallingford.

Milano, C., Novelli, M. and Cheer, J. (2019), “Editorial: Overtourism and Tourismphobia: A journey through four decades of tourism development, planning and local concerns", Tourism Planning \& Development, Vol. 16 No 4, pp. 353-357.

Muler Gonzalez, V., Coromina, L. and Gali, N. (2018), “Overtourism: residents' perceptions of tourism impact as an indicator of resident social carrying capacity-case study of a Spanish heritage town", Tourism Review, Vol. 73 No 3, pp. 277-296.

Namberger, P., Jackisch, S., Schmude, J. and Karl, M. (2019), “Overcrowding, overtourism and local level disturbance: How much can Munich handle?", Tourism Planning \& Development, Vol. 16 No 4, pp. 452-472. 
Oltermann, P. (2016, 8 June), "Berlin ban on Airbnb short-term rentals upheld by city court", The Guardian, available at: https://www.theguardian.com/technology/2016/jun/08/berlin-banairbnb-short-term-rentals-upheld-city-court (accessed July 29, 2019).

Oskam, J. A. (2019), The Future or Airbnb and the 'Sharing Economy', Channel View Publications, Clevedon.

Page, S. J. and Hall, C. M. (2003), Managing Urban Tourism: Prentice Hall, Harlow.

Panayiotopoulos, A. And Pisano, C. (2019), "Overtourism dystopias and socialist utopias: Towards an urban armature for Dubrovnik", Tourism Planning \& Development, Vol. 16 No 4, pp. 393-410,

Pearce, D.G. (1998), "Tourist districts in Paris: structure and functions", Tourism Management, Vol. 19 No 1, pp.49-65.

Pike, S and Page, S. J. (2014), "Destination Marketing Organizations and destination marketing: A narrative analysis of the literature", Tourism Management, Vol 41, pp. 202-227

Rickley, J. M. (2019), "Overtourism and authenticity", in Dodds, R. and Butler, R. W. (Eds.), Overtourism: Issues, Realities and Solutions, De Gruyter, Berlin, pp. 46-61.

Seraphin, H. Gowreesunkar, V., Zaman, M. and Bourliataux-Lajoinie, S. (2018), "Community based festivals as a tool to tackle tourismphobia and antitourism movements", Journal of Hospitality and Tourism Management, Vol. 39, pp. 219-223.

Seraphin, H., Sheeran, P. and Pilato, M. (2018), "Over-tourism and the fall of Venice as a destination", Journal of Destination Marketing \& Management, Vol. 9, pp.374-376.

SmartPrague (2017), "Prague Visitor Guide", available at: https://smartprague.eu/projects/praguevisitor-guide (accessed August 22, 2019).

Smith, M. K., Sziva, I. P. and Olt, G. (2019), “Overtourism and Resident Resistance in Budapest, Tourism Planning \& Development, Vol. 16 No 4, pp. 376-392.

Souliotis, N. (2013), "Cultural economy, sovereign debt crisis and the importance of local contexts: The case of Athens", Cities, Vol. 33, pp.61-68. 
Themed Entertainment Association (TEA) and AECOM (2019), Theme Index and Museum Index: The Global Attractions Attendance Report, TEA, Burbank.

Tulumello, S. (2016), "Reconsidering neoliberal urban planning in times of crisis: Urban regeneration policy in a "dense" space in Lisbon", Urban Geography, Vol. 37 No 1, pp. 117-140.

United Nations World Tourism Organization (UNWTO) (2012), Global Report on City Tourism, UNWTO, Madrid.

United Nations World Tourism Organization (UNWTO) (2014), Global Benchmarking for City Tourism Measurement, UNWTO, Madrid.

United Nations World Tourism Organization (UNWTO) (2018), 'Overtourism'? Understanding and Managing Urban Tourism Growth beyond Perceptions, UNWTO, Madrid.

van der Borg, J. (2001), "La gestione del turismo nelle città d'arte”, in Costa, P., Manente, M. and Furlan, F. C. (Eds.), Politica Economica del Turismo: Lezioni, Modelli di Gestione e Casi Studio Italiani e Stranieri, Touring University Press, Milan, pp. 205-236.

van der Borg, J., Costa, P and Gotti, G. (1996), "Tourism in European heritage cities", Annals of Tourism Research, Vol. 23 No 2, pp. 306-321.

Visentin, F. and Bertocchi, D. (2019), "Venice: An analysis of tourism excesses in an overtourism icon", in Milano, C., Cheer, J. M. and Novelli, M. (Eds.), Overtourism: Excesses, Discontents and Measures in Travel and Tourism, CABI, Wallingford, pp. 18-38.

VisitBritain (2018), Top Towns for 'Staying Visits' by Inbound Visitors, VisitBritain, London.

Volgger, M. and Pechlaner, H. (2014), "Requirements for destination management organizations in destination governance: Understanding DMO success", Tourism Management, Vol. 41, pp. 6475.

Wall, G. (2019), "Perspectives on the environment and overtourism", in Dodds, R. and Butler, R. W. (Eds.), Overtourism: Issues, Realities and Solutions, De Gruyter, Berlin, pp. 27-45.

Weaver, D. B. (2000), "A broad context model of destination development scenarios", Tourism Management, Vol. 21 No 3, pp. 217-224. 
World Travel and Tourism Council (WTTC) (2018), City Travel \& Tourism Impact 2018, WTTC, London.

Yanes, S. (2019), “Recuperar el barrio. Maniobras de transformación urbana en la Ciudad Vieja de Montevideo", in Milano, C. and Mansilla, J. A. (Eds.), Ciudad de Vacaciones. Conflictos Urbanos en Espacios Turísticos, Pol-len Edicions, Barcelona, pp. 439-471.

Zervas. G., Proserpio, D. and Byers, J. (2017), “The rise of the sharing economy: Estimating the impact of Airbnb on the hotel industry", Journal of Marketing Research, Vol. 54, pp. 687-705. 
Table 1: Correlation of the overtourism indicators*

\begin{tabular}{l|l|c|c|c} 
& & $\begin{array}{c}\text { Total overnight stays } \\
\text { per surface }\end{array}$ & $\begin{array}{c}\text { Number of museum } \\
\text { visitors per resident }\end{array}$ & $\begin{array}{l}\text { Change in total } \\
\text { overnight stays }\end{array}$ \\
\hline $\begin{array}{l}\text { Number of museum visitors } \\
\text { per resident }\end{array}$ & $R$ & 0.07 & & \\
\hline Change in total overnight & $R$ & 0.82 & -0.18 & 0.52 \\
stays & $p$-value & -0.52 & 0.93 & -0.10 \\
\hline Foreign overnight stays per & $R$ & 0.05 & 0.00 & 0.73
\end{tabular}

*Note: The number of observations is 15. 
2

3

4

5

6

7

8

Table 2: Indicators of overtourism of selected European cities

\begin{tabular}{|c|c|c|c|c|}
\hline & $\begin{array}{c}\text { Total overnight stays } \\
\text { per surface }\end{array}$ & $\begin{array}{l}\text { Number of museum } \\
\text { visitors per resident }\end{array}$ & $\begin{array}{l}\text { Change in total } \\
\text { overnight stays }\end{array}$ & $\begin{array}{c}\text { Foreign overnight stays } \\
\text { per resident }\end{array}$ \\
\hline & Million per km² (2017) & $\begin{array}{l}\text { Million per city } \\
\text { population (2017) }\end{array}$ & $\begin{array}{c}\text { average growth rate } \\
(2009-2017) \text { in \% }\end{array}$ & $\begin{array}{l}\text { Million per city } \\
\text { population (2017) }\end{array}$ \\
\hline Amsterdam & 3.3 & 10.1 & 6.6 & 16.0 \\
\hline Barcelona & 1.9 & 3.9 & 6.1 & 10.4 \\
\hline Berlin & 2.9 & 4.5 & 5.9 & 3.9 \\
\hline Edinburgh & 1.2 & 13.5 & 4.5 & 7.9 \\
\hline Florence & 11.2 & 37.6 & 4.3 & 15.0 \\
\hline Copenhagen & 0.7 & 6.0 & 5.5 & 7.5 \\
\hline Lisbon & 0.3 & 8.6 & 9.6 & 17.3 \\
\hline London & 9.4 & 7.6 & 0.7 & 4.5 \\
\hline Madrid & 3.8 & 3.1 & 5.1 & 3.7 \\
\hline Paris & 5.5 & 3.5 & 2.4 & 10.9 \\
\hline Prague & 2.6 & 2.4 & 5.7 & 12.5 \\
\hline Rome & 5.0 & 7.2 & 3.7 & 7.0 \\
\hline Sevilla & 5.4 & 3.8 & 8.1 & 4.7 \\
\hline Venice & 1.9 & 83.2 & 3.9 & 124.4 \\
\hline Wien & 2.5 & 6.1 & 4.4 & 7.2 \\
\hline
\end{tabular}

Source: http://www.tourmis.info/, Eurostat (Culture and tourism - cities and greater cities [urb_ctour] database: Number of museum visitors (per year), Total nights spent in tourist accommodation establishments, population), OECD, national statistical offices, own calculations. 
Table 3: Composite indicator of overtourism of selected European cities

\begin{tabular}{l|c|c} 
& z score standardised & Rank \\
\hline Venice & 1.4 & 1 \\
Florence & 0.8 & 2 \\
Seville & 0.3 & 3 \\
Lisbon & 0.2 & 4 \\
Amsterdam & 0.1 & 5 \\
Berlin & -0.2 & 6 \\
Prague & -0.2 & 7 \\
Barcelona & -0.2 & 8 \\
Rome & -0.2 & 9 \\
London & -0.2 & 10 \\
Madrid & -0.2 & 11 \\
Paris & -0.3 & 12 \\
Wien & -0.4 & 13 \\
Edinburgh & -0.4 & 14 \\
Copenhagen & -0.4 & 15 \\
& &
\end{tabular}




\section{Appendices}

Appendix I Indicators used to calculate the overtourism indicator

Surface
Area of the Top 10
attractions
in km2
10.6
6.5
5.6
11.0
1.1
5.5
0.9
42.5
6.3
7.0
10.8
7.0
8.3
6.9
4.8

Overnight stays

Total
number
2017

$18.9 \quad 16.2$

10.5

14.5

12.6

3.2

18.6

6.6

5.7

8.9

11.2

4.2

32.5

65.0

0.0
Foreign overnight stays

Total

number

2017
Population

Narrow def. in $1000 \mathrm{~s}$ 2017

Source: tourmis, Eurostat, OECD, national statistical offices, own calculations. 


\begin{tabular}{|c|c|c|c|c|}
\hline Amsterdam & Barcelona & Berlin & Copenhagen & Edinburgh \\
\hline Rijksmuseum & Sagrada Familia & Reichstagsgebäude & Nyhavn & Arthur's Seat \\
\hline & & Gedenkstätte & & National Museum \\
\hline Anne Frank House & Casa Batllo & Mauer & Tivoli Gardens & Scotland \\
\hline Van Gogh Museum & Barri Gotic & Topographie des Terrors & The David Collection & Edinburgh Old Town \\
\hline & Palau de la Musica & & & Camera Obscura and \\
\hline The Jordaan & catalana & Brandenburg Gate & Grundtvig Church & World of Illusions \\
\hline Vondelpark & Casa Mila & Holocaust-Mahnmal & Torvehallerne & Royal Mile \\
\hline Centraal Station & Camp Nou & Pergamonmuseum & Copenhagen Visitor Service & Edinburgh Castle \\
\hline & Basilika Santa Maria del & & & The Real Mary King's \\
\hline Heineken Experience & Mar & East Side Gallery & Frederiksberg Have & Close \\
\hline Dam Square & Mercat de la Boqueria & Urban Nation & Royal Library & Pickering's Gin Distillery \\
\hline Museum Ons'Lieve Op Solder & $\begin{array}{l}\text { The Magic Fountain } \\
\text { Recinte Modernista de }\end{array}$ & Berliner Philharmonie & The Hirschsprung Collection & BobCat Alpacas \\
\hline Red Light District & Sant Pau & nineties berlin & Ny Carlsberg Glyptotek & Edinburgh Gin Distillery \\
\hline Florence & Lisbon & London & Madrid & Paris \\
\hline Gallerie Degli Uffizi & Oceanario de Lisbon & National Gallery & Parque del Retiro & Musee d'Orsay \\
\hline Piazzale Michelangelo & Alfama & Churchill War Rooms & Prado National Museum & Sainte-Chapelle \\
\hline $\begin{array}{l}\text { Duomo-Cattedrale di Santa } \\
\text { Maria del Fiore }\end{array}$ & Mosteiro dos Jeronimos & St. James Park & $\begin{array}{l}\text { Museo Nacional Thyssen- } \\
\text { Bornemisza }\end{array}$ & $\begin{array}{l}\text { Palais Garnier- Opera } \\
\text { National der Paris }\end{array}$ \\
\hline Piazza Del Duomo & Praca do Comercio & $\begin{array}{l}\text { The British Museum } \\
\text { V\&A- Vistoria and Albert }\end{array}$ & Stadio Santiago Bernabeu & Musee de l'Orangerie \\
\hline Galleria dell'Accademia & Bairro Alto & Museum & Royal Palace of Madrid & Pont Alexandre III \\
\hline Basilica di Santa Croce & Castelo de Sao Jorge & Hyde Park & $\begin{array}{l}\text { Museo Nacional Centro de } \\
\text { Arte Reina Sofia }\end{array}$ & $\begin{array}{l}\text { Cathedrale Notre-Dame } \\
\text { de Paris }\end{array}$ \\
\hline Palazzo Vechio & Belem & Tower Bridge & Gran Via & Luxembourg Gardens \\
\hline Cupola del Brunelleschi & The Best Portugal & Tower of London & Plaza Major & Musee Rodin \\
\hline Palazzo Pitti & Tram 28 & Houses of Parliament & Mercado San Miguel & Le Marais \\
\hline Museo del'Opera del Duomo & Miradouro da Senhora & Borough Market & Templo de Debod & Eiffel Tower \\
\hline Prague & Rome & Seville & Venice & Vienna \\
\hline St. Vitus Cathedral & Colosseum & Plaza de Espana & Old city sestriere & $\begin{array}{l}\text { Schönbrunn Palace } \\
\text { Kunsthistorisches }\end{array}$ \\
\hline StaromEstske namEsti & Pantheon & Alacazar & Old city sestriere & Museum Vienna \\
\hline Charles Bridge & Romen Forum & Catedral de Sevilla & Old city sestriere & $\begin{array}{l}\text { Historic Center of Vienna } \\
\text { Tiergarten Schönbrunn- }\end{array}$ \\
\hline Prague Castle & Palatine Hill & Centro Historico de Sevilla & Old city sestriere & Zoo Vienna \\
\hline $\begin{array}{l}\text { Old Town Hall with astronomial } \\
\text { clock }\end{array}$ & $\begin{array}{l}\text { Basilica di Santa maria } \\
\text { Maggiore }\end{array}$ & $\begin{array}{l}\text { Jardines de los Reales } \\
\text { Alcazares }\end{array}$ & Old city sestriere & Imperial Palace \\
\hline NaFILM: National fil museum & Galleria Borghese & Barrio Santa Cruz & Old city sestriere & Belvedere Museum \\
\hline Czech Repubrick & Trevi Fountain & Maria- Luisa - Park & Old city sestriere & Albertina \\
\hline National Memorail to the & & & & \\
\hline Hereos of the Heydrich Terror & Piazza Navona & $\begin{array}{l}\text { Giralda } \\
\text { Iglesia de Santa Maria la }\end{array}$ & Old city sestriere & National History Museum \\
\hline Gallery of Steel & Trastevere & Blanca & Old city sestriere & Wiener Staatsoper \\
\hline $\begin{array}{l}\text { St Cyril and St Methodius } \\
\text { Cathedral }\end{array}$ & $\begin{array}{l}\text { Museo Nazionale di } \\
\text { Castel Sant' Angelo }\end{array}$ & $\begin{array}{l}\text { Estadio Ramon Sanchez- } \\
\text { Pizjuan }\end{array}$ & Old city sestriere & St. Stephen's Cathedral \\
\hline
\end{tabular}

Source: own calculation based on tripadvisor. 
Appendix 3: Evolution of nights spent at tourist accommodation establishments

\begin{tabular}{|c|c|c|c|c|c|c|}
\hline & Total & & & Cities & & \\
\hline & 2012 & 2017 & Average & 2012 & 2017 & Average. \\
\hline & & & Growth rates & & & Growth rates \\
\hline Austria & 109540720 & 121126543 & 2.0 & 18182420 & 21973477 & 3.9 \\
\hline Belgium & 31267441 & 38677308 & 4.3 & 12841642 & 14709613 & 2.8 \\
\hline Bulgaria & 20252038 & 26054096 & 5.2 & 7083786 & 8842343 & 4.5 \\
\hline Croatia & 62183925 & 86094847 & 6.7 & 2101188 & 4820849 & 18.1 \\
\hline Czechia & 43278457 & 53219395 & 4.2 & 19466080 & 24223620 & 4.5 \\
\hline Denmark & 28040235 & 32157794 & 2.8 & 8588292 & 11339879 & 5.7 \\
\hline France & 400525558 & 433058728 & 1.6 & 151984307 & 165197276 & 1.7 \\
\hline Germany & 350349425 & 401163218 & 2.7 & 124344548 & 152643424 & 4.2 \\
\hline Greece & 80566672 & 111271482 & 6.7 & 8150335 & 11743290 & 7.6 \\
\hline Hungary & 23169533 & 31608719 & 6.4 & 9397162 & 13022395 & 6.7 \\
\hline Italy & 380711483 & 420629155 & 2.0 & 99221514 & 118427378 & 3.6 \\
\hline Netherlands & 84050408 & 111697814 & 5.9 & 24573788 & 37774776 & 9.0 \\
\hline Poland & 62014890 & 83880915 & 6.2 & 19917860 & 28551742 & 7.5 \\
\hline Portugal & 46781091 & 72035786 & 9.0 & 19356321 & 31940609 & 10.5 \\
\hline Romania & 19091379 & 26915573 & 7.1 & 8281088 & 12025139 & 7.7 \\
\hline Slovakia & 10770328 & 14667937 & 6.4 & 2547413 & 3826002 & 8.5 \\
\hline Spain & 382670976 & 471199729 & 4.2 & 116203993 & 171074161 & 8.0 \\
\hline Sweden & 48585972 & 58683201 & 3.8 & 17826453 & 23692376 & 5.9 \\
\hline United Kingdom & 303564528 & 476356101 & 11.9 & 155124014 & 300859741 & 18.0 \\
\hline European Union - 28 & 2585808714 & 3184056269 & 4.3 & 856449916 & 1199773734 & 7.0 \\
\hline & Towns and $s$ & suburbs & & Rural areas & & \\
\hline & 2012 & 2017 & Average & 2012 & 2017 & Average \\
\hline & & & Growth rates & & & Growth rates \\
\hline Austria & 16953051 & 18639233 & 1.9 & 74405249 & 80513833 & 1.6 \\
\hline Belgium & 12264285 & 17120635 & 6.9 & 6161514 & 6847060 & 2.1 \\
\hline Bulgaria & 7570703 & 10742970 & 7.3 & 5597549 & 6468783 & 2.9 \\
\hline Croatia & 18059929 & 25649248 & 7.3 & 42022808 & 55624750 & 5.8 \\
\hline Czechia & 7283025 & 9129767 & 4.6 & 16529352 & 19866008 & 3.7 \\
\hline Denmark & 3230348 & 3622348 & 2.3 & 16221595 & 17195567 & 1.2 \\
\hline France & 94849224 & 101130691 & 1.3 & 153692028 & 166730760 & 1.6 \\
\hline Germany & 107185103 & 120235036 & 2.3 & 118464804 & 128284758 & 1.6 \\
\hline
\end{tabular}




$\begin{array}{lrrrrrrr}\text { Greece } & 19995315 & 27412362 & 6.5 & 52421022 & 72115830 & 6.6 \\ \text { Hungary } & 2670387 & 10736925 & 32.1 & 11101984 & 7849399 & -6.7 \\ \text { Italy } & 145251144 & 183661424 & 4.8 & 136238825 & 118540353 & -2.7 \\ \text { Netherlands } & 31503419 & 38132510 & 3.9 & 27973202 & 35790528 & 5.1 \\ \text { Poland } & 21407133 & 30642514 & 7.4 & 20689897 & 24686659 & 3.6 \\ \text { Portugal } & 19649402 & 28064161 & 7.4 & 7775368 & 12031016 & 9.1 \\ \text { Romania } & 6650659 & 8738224 & 5.6 & 4159632 & 6152210 & 8.1 \\ \text { Slovakia } & 3376752 & 4637572 & 6.6 & 4846163 & 6204363 & 5.1 \\ \text { Spain } & 151023184 & 242141326 & 9.9 & 115443799 & 57984242 & -12.9 \\ \text { Sweden } & 11694593 & 13825592 & 3.4 & 19064926 & 21165233 & 2.1 \\ \text { United Kingdom } & 74369412 & 95232920 & 6.4 & 74072102 & 80263450 & 2.0 \\ \text { European Union }-28 & 785208971 & 1024985886 & 5.5 & 938402058 & 959296646 & 0.4\end{array}$

Note: Data for the UK refers to the period 2012-2016 and are based on estimated and interpolated figures (domestic travel survey and passenger survey at main entry points). Source: Eurostat. Nights spent at tourist accommodation establishments (Hotels; holiday and other short-stay accommodation; camping grounds, recreational vehicle parks and trailer parks) by NUTS 2 regions [tour_occ_nin2]. 


\section{Appendix 4}

Graph 1: Calculation of the surface of the TOP 10 attractions according to Tripadvisor using google Map

Amsterdam $=32$ square kilometre

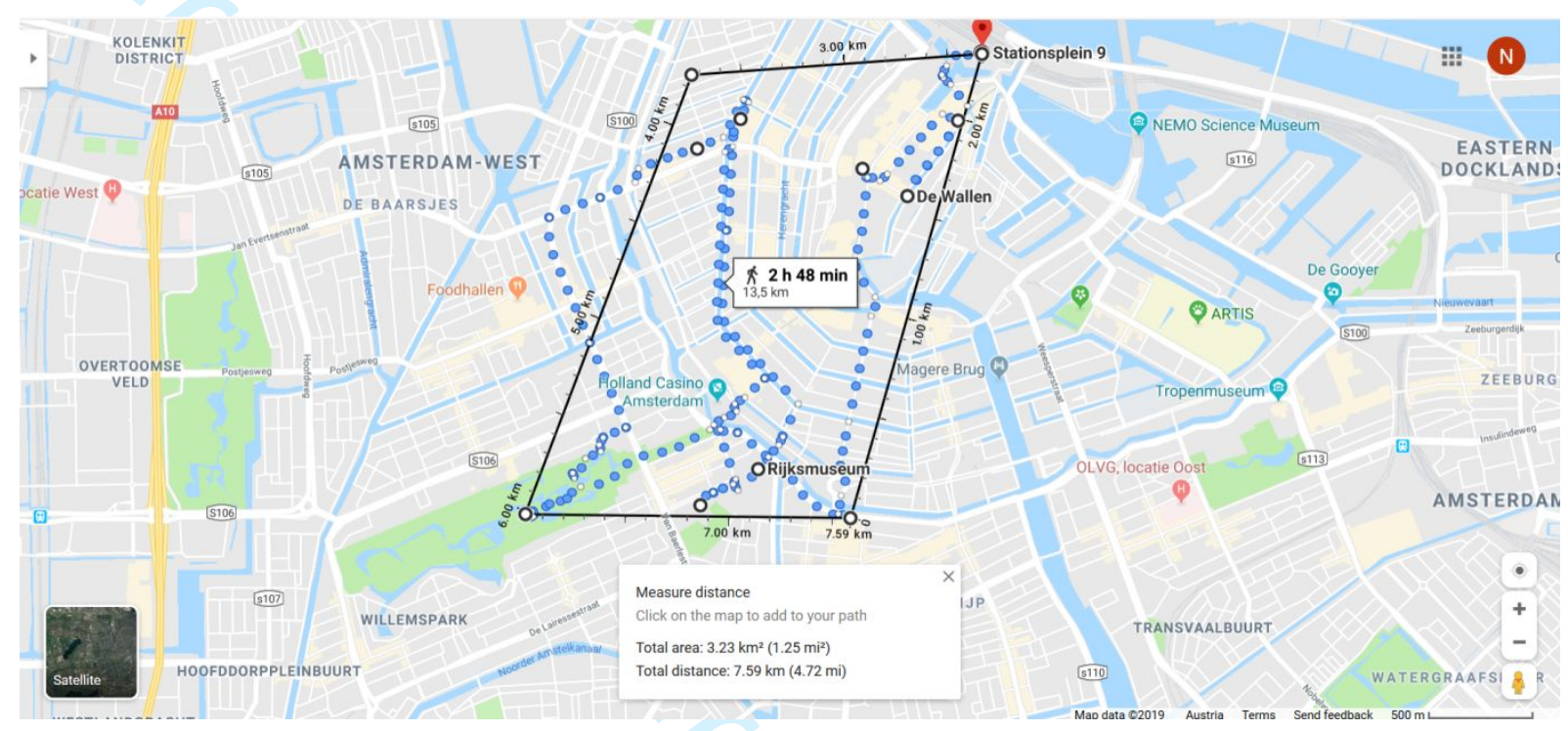

Barcelona=10.9 square kilometre

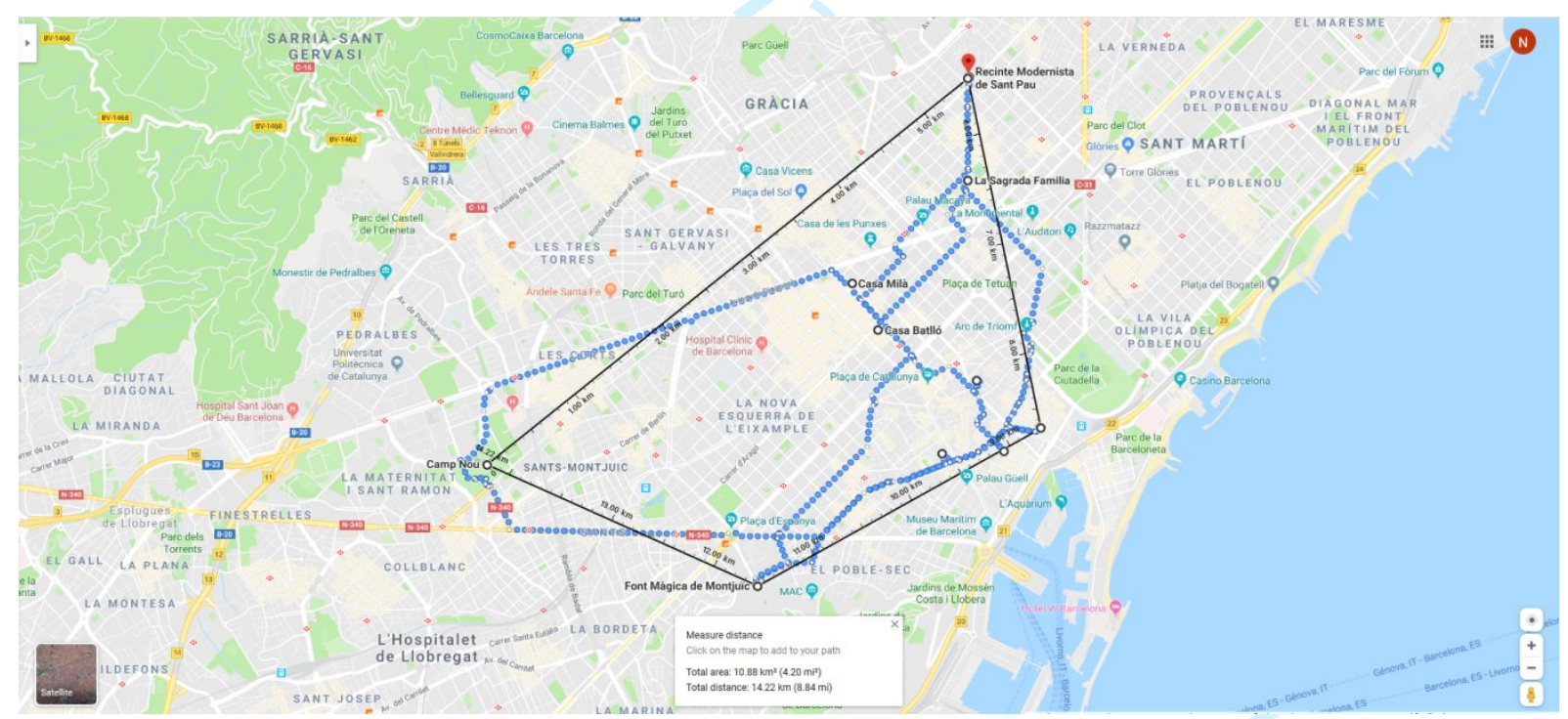


Berlin $=10.6$ square kilometre

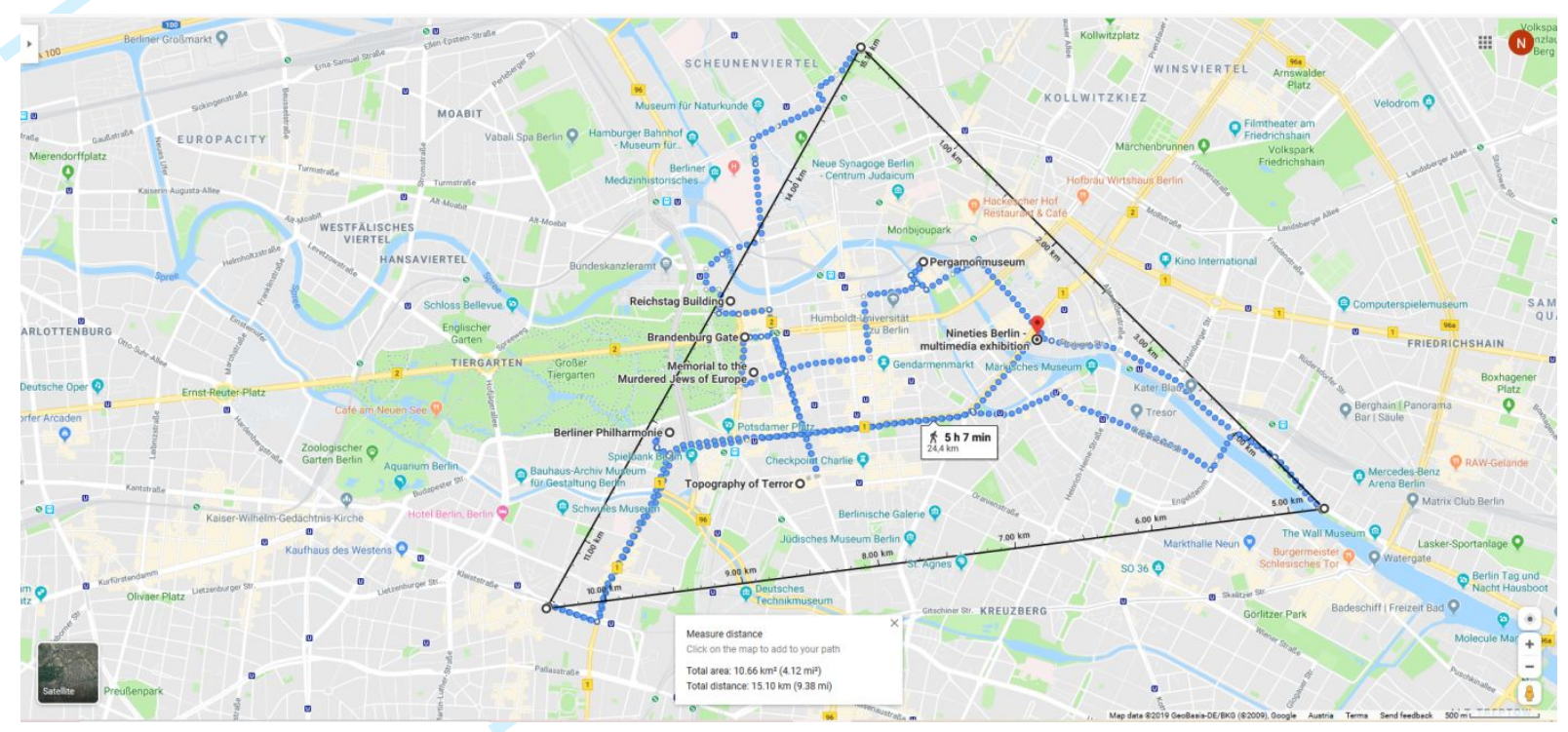

Copenhagen $=10.8$ square kilometre

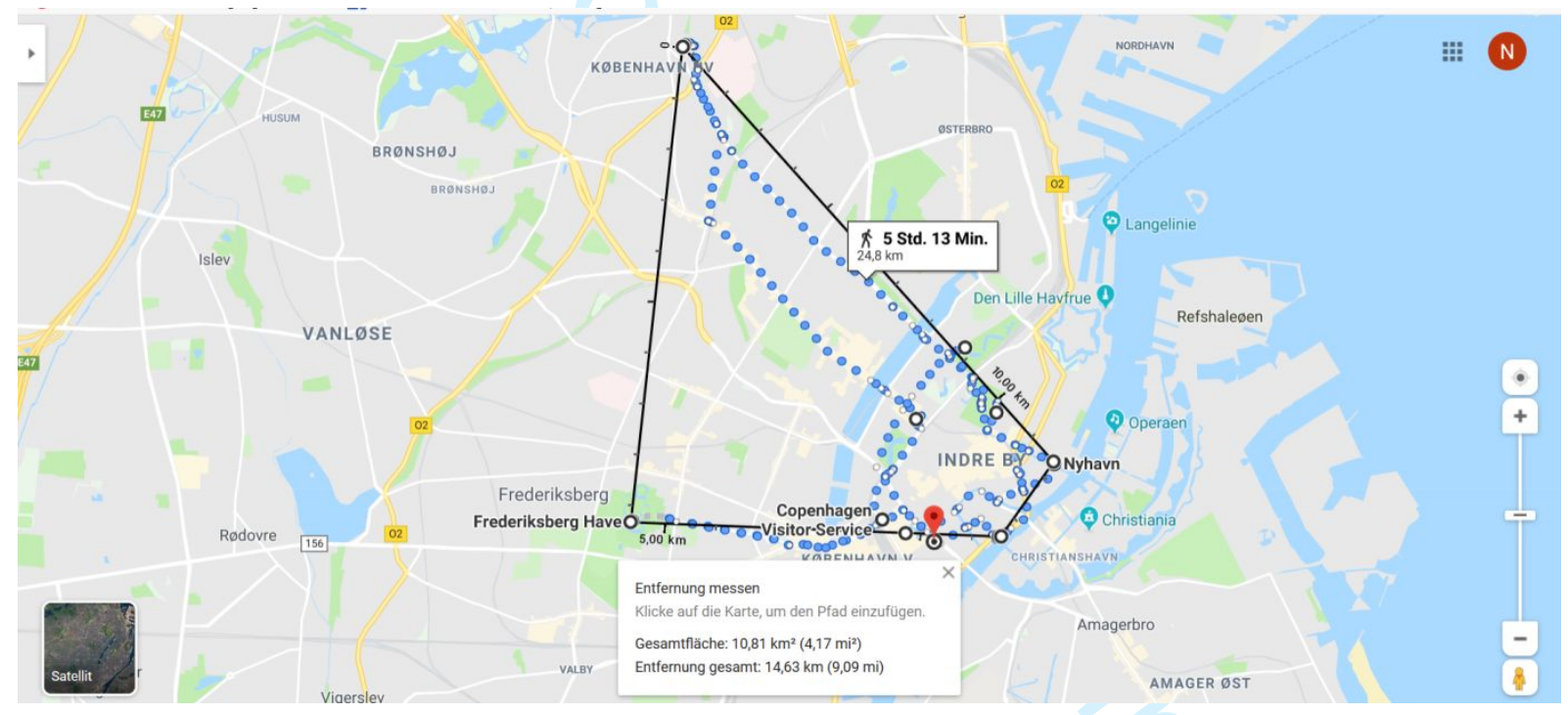


Edinburgh= 6.9 square kilometre

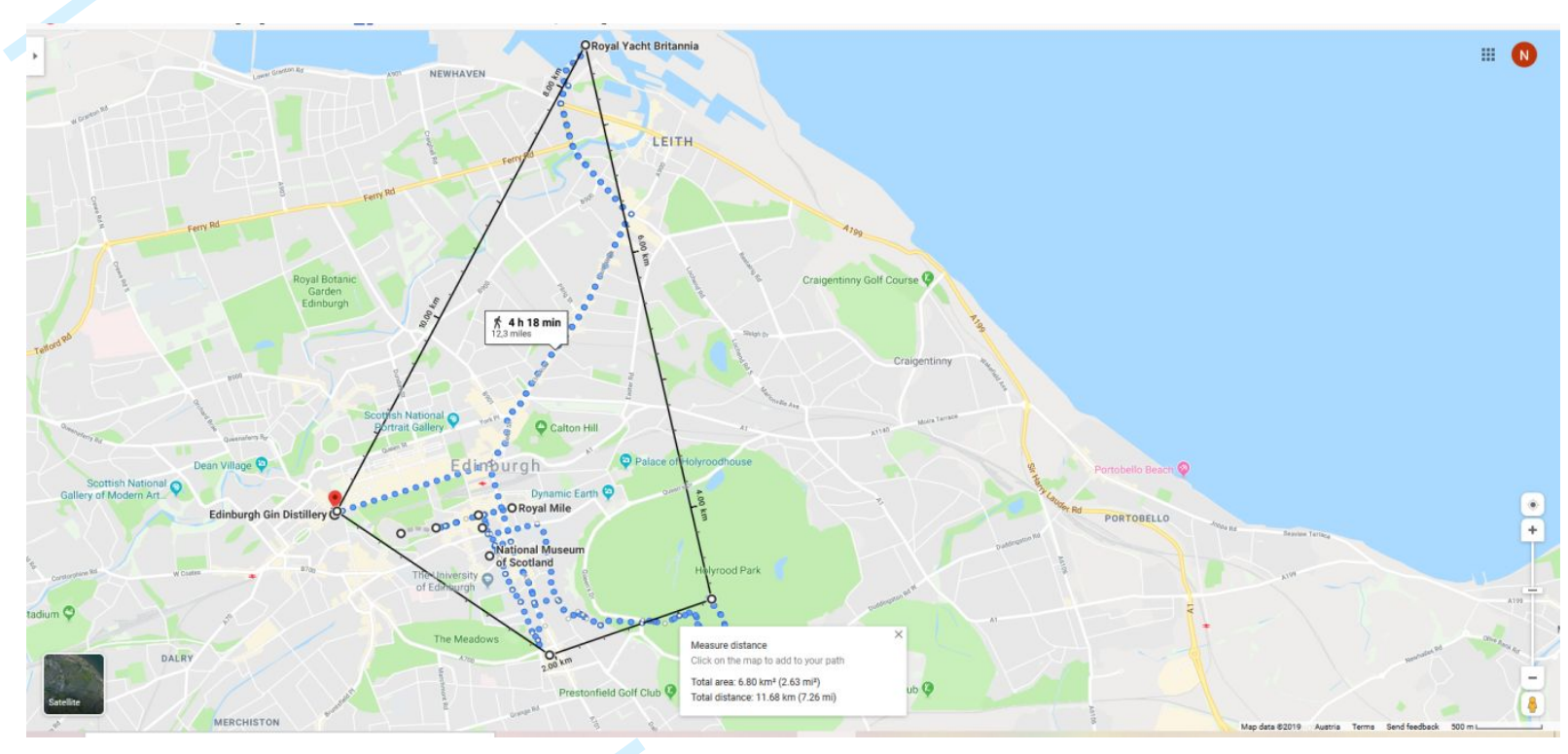

Florence $=0,86$ square kilometre

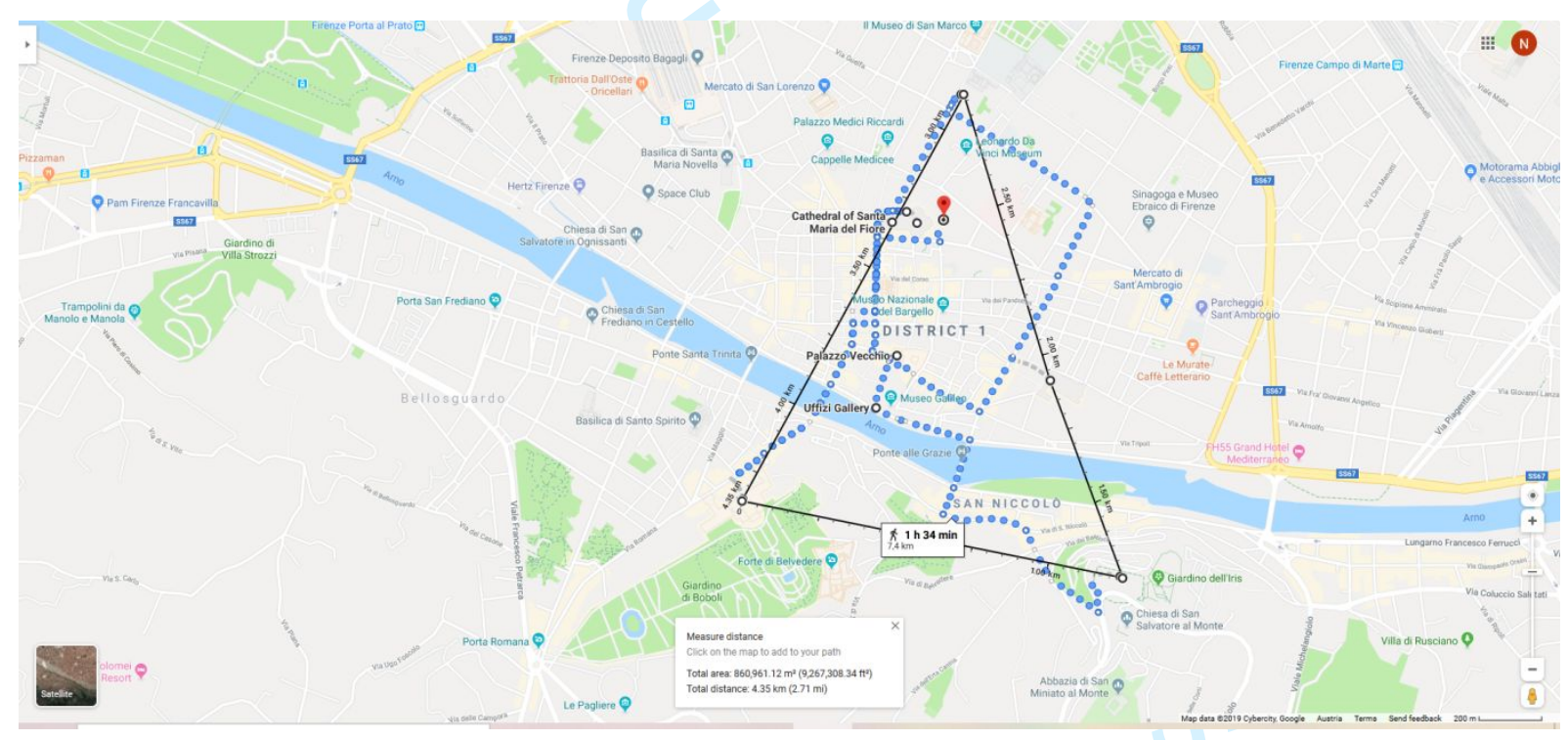


Lisbon $=42.5$ square kilometre

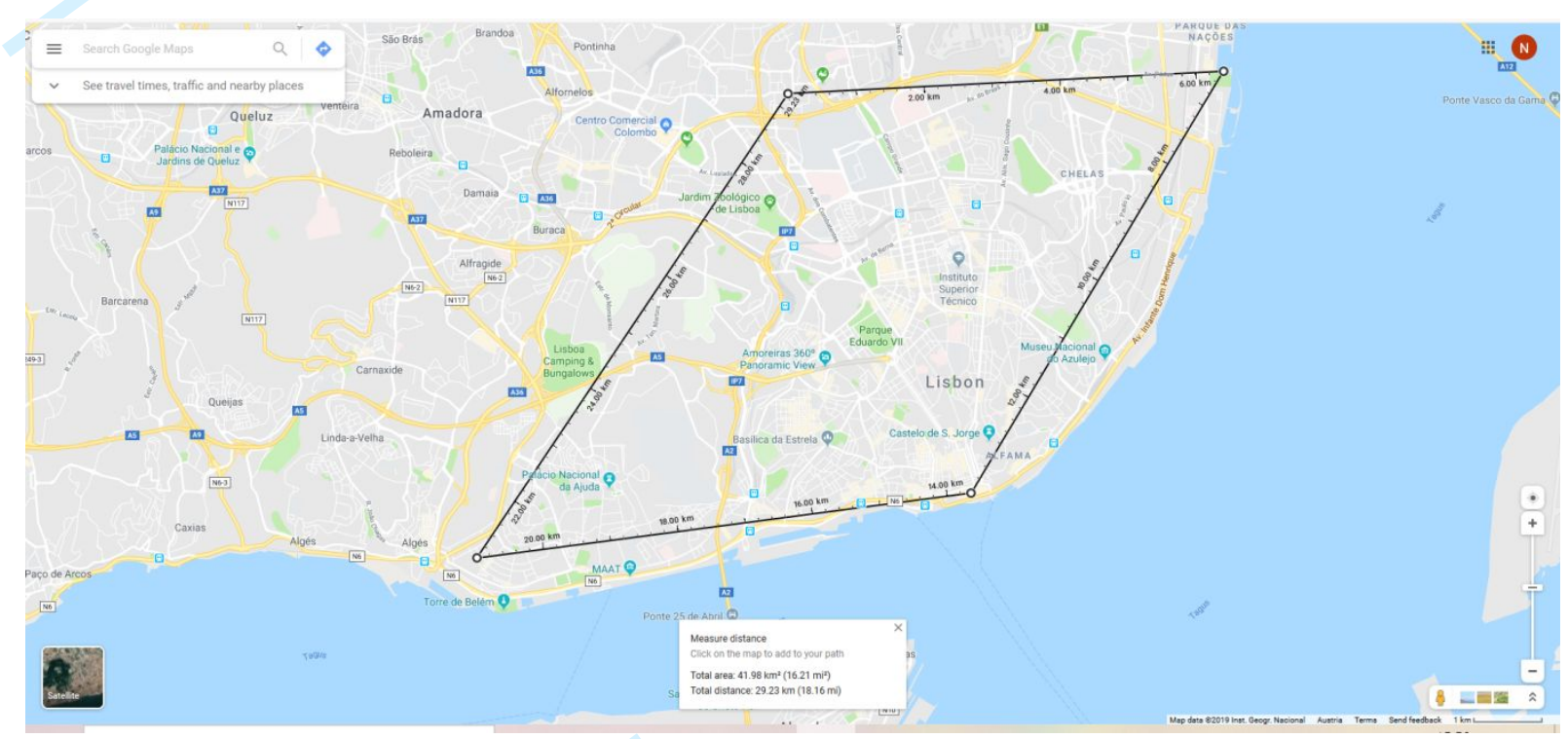

London $=8.5$ square kilometre

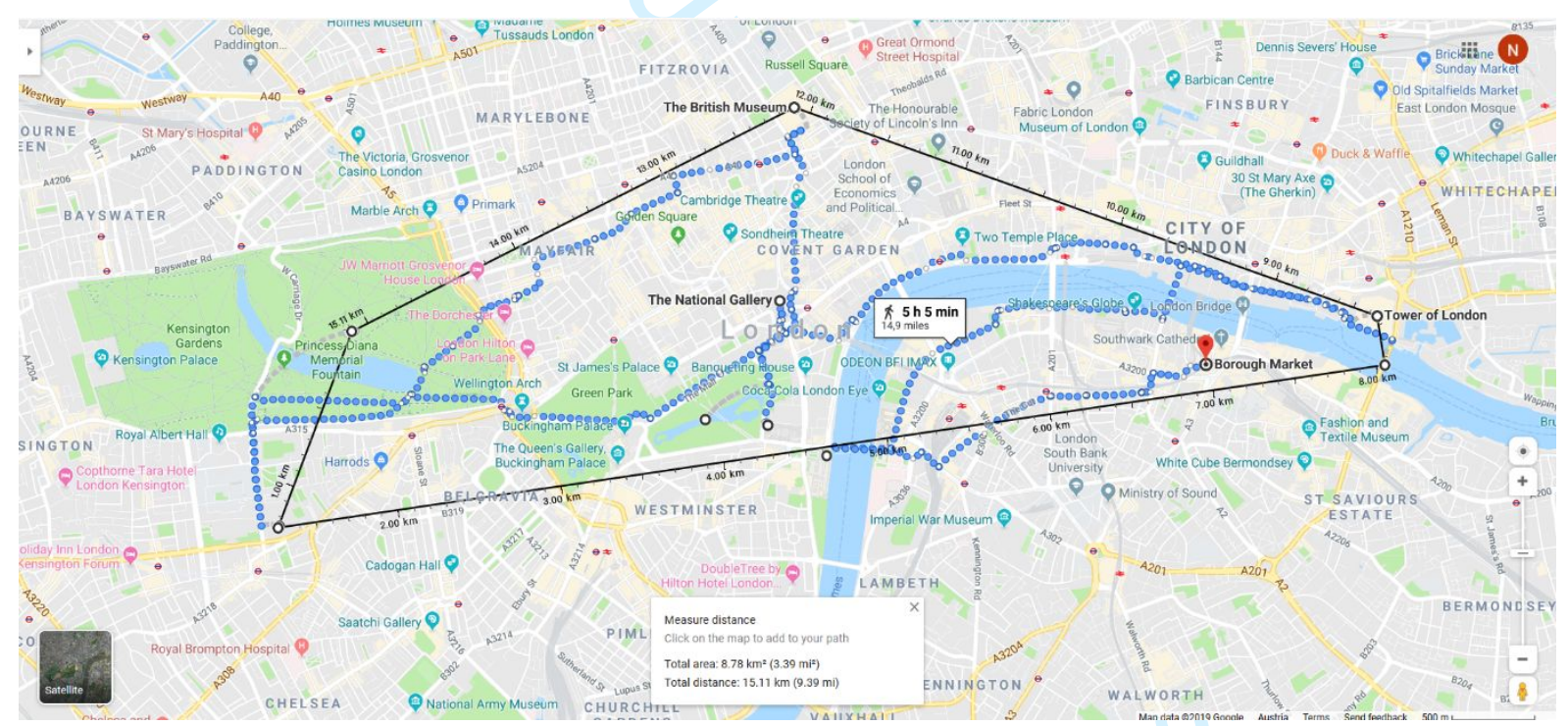


Madrid $=7.7$ square kilometre

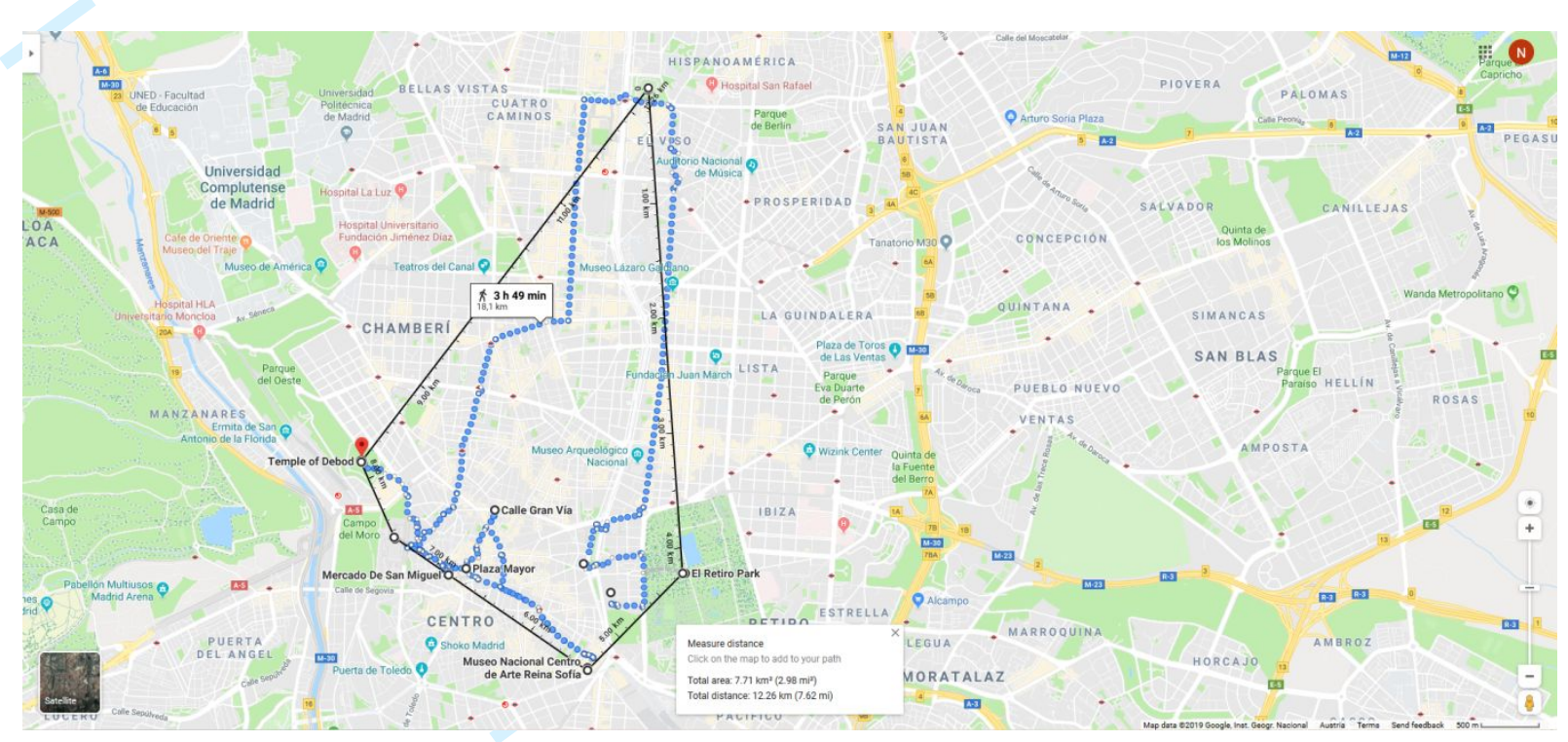

Paris $=7.1$ square kilometre

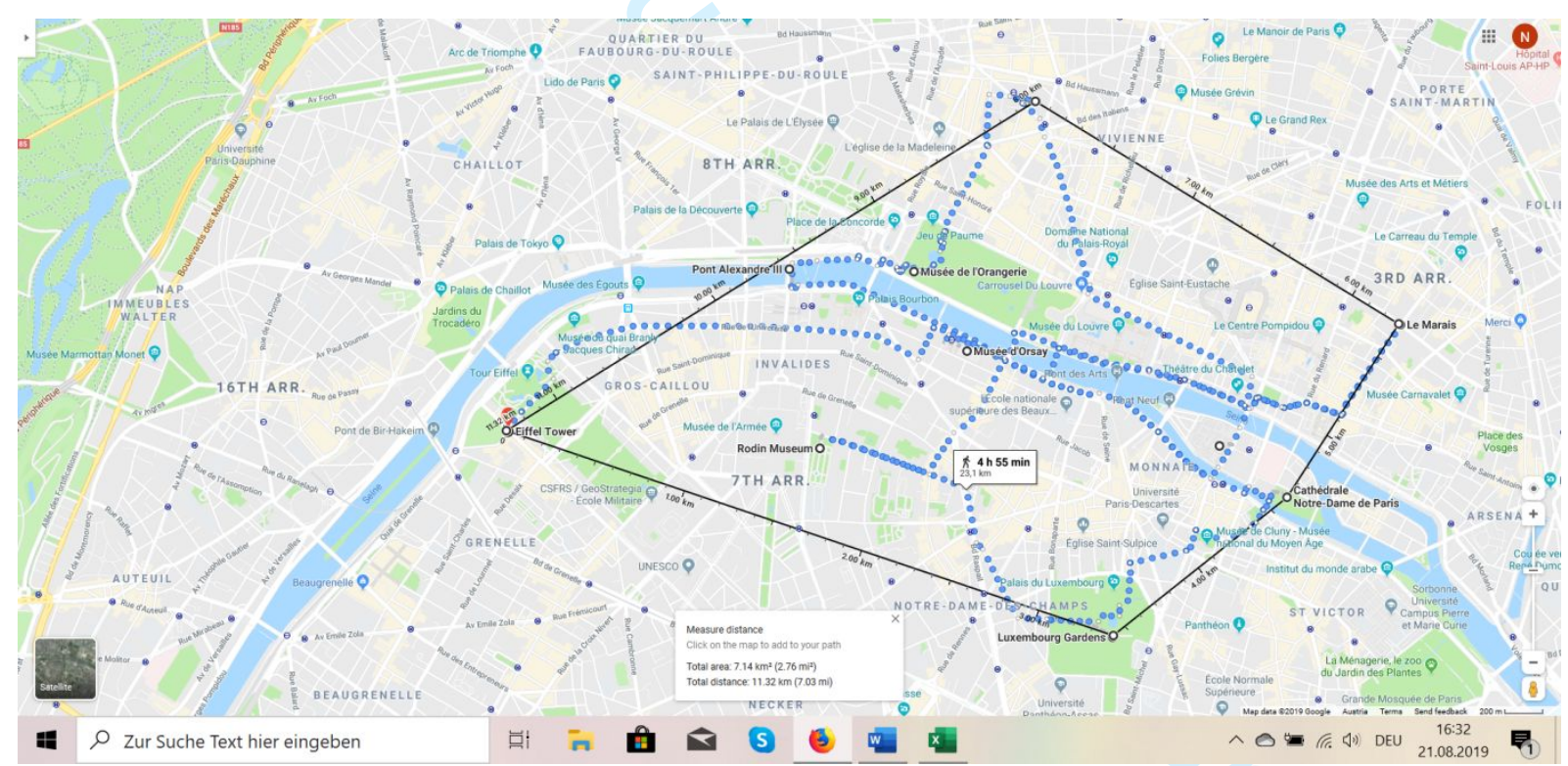


Prague $=1.3$ square kilometre

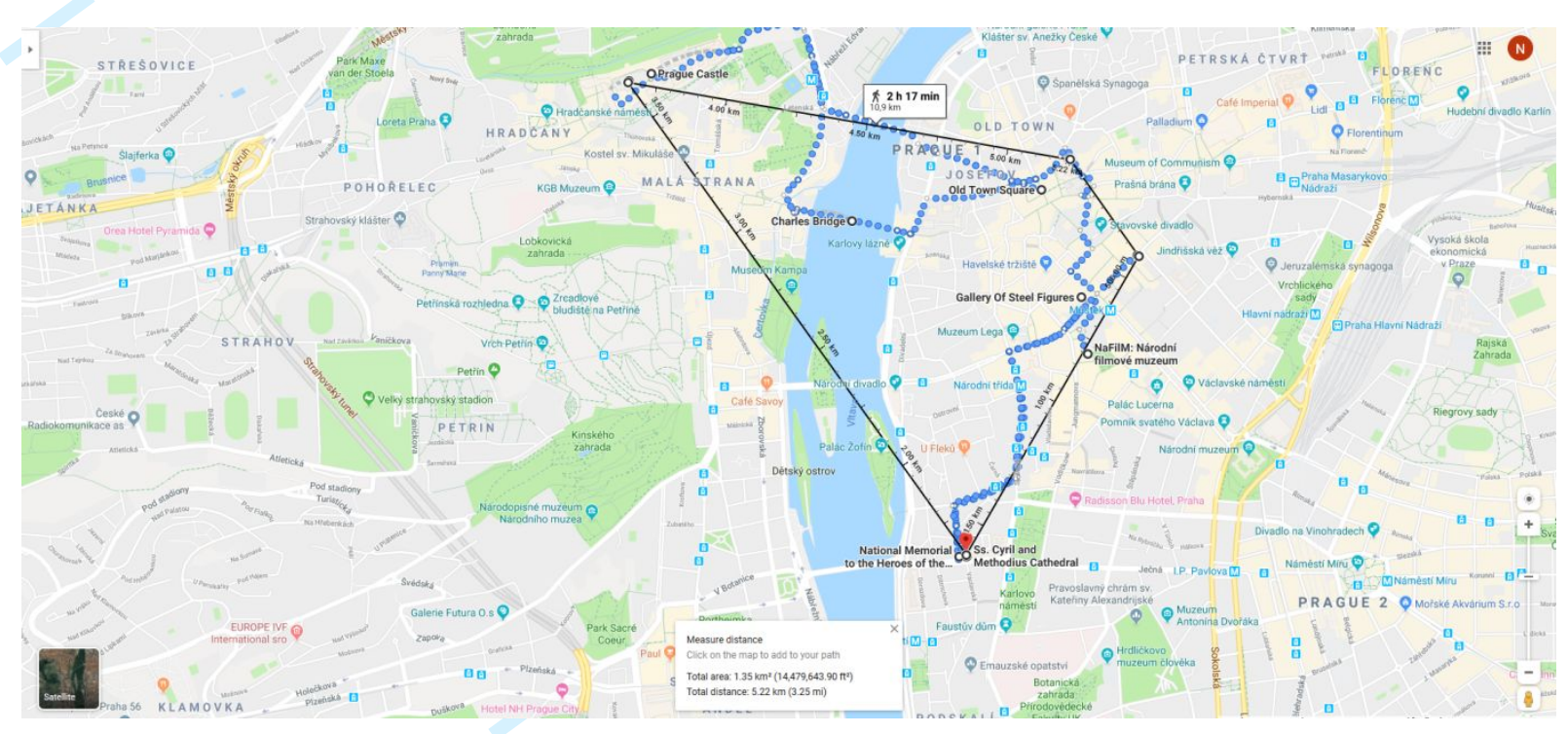

Rome $=5.5$ square kilometre

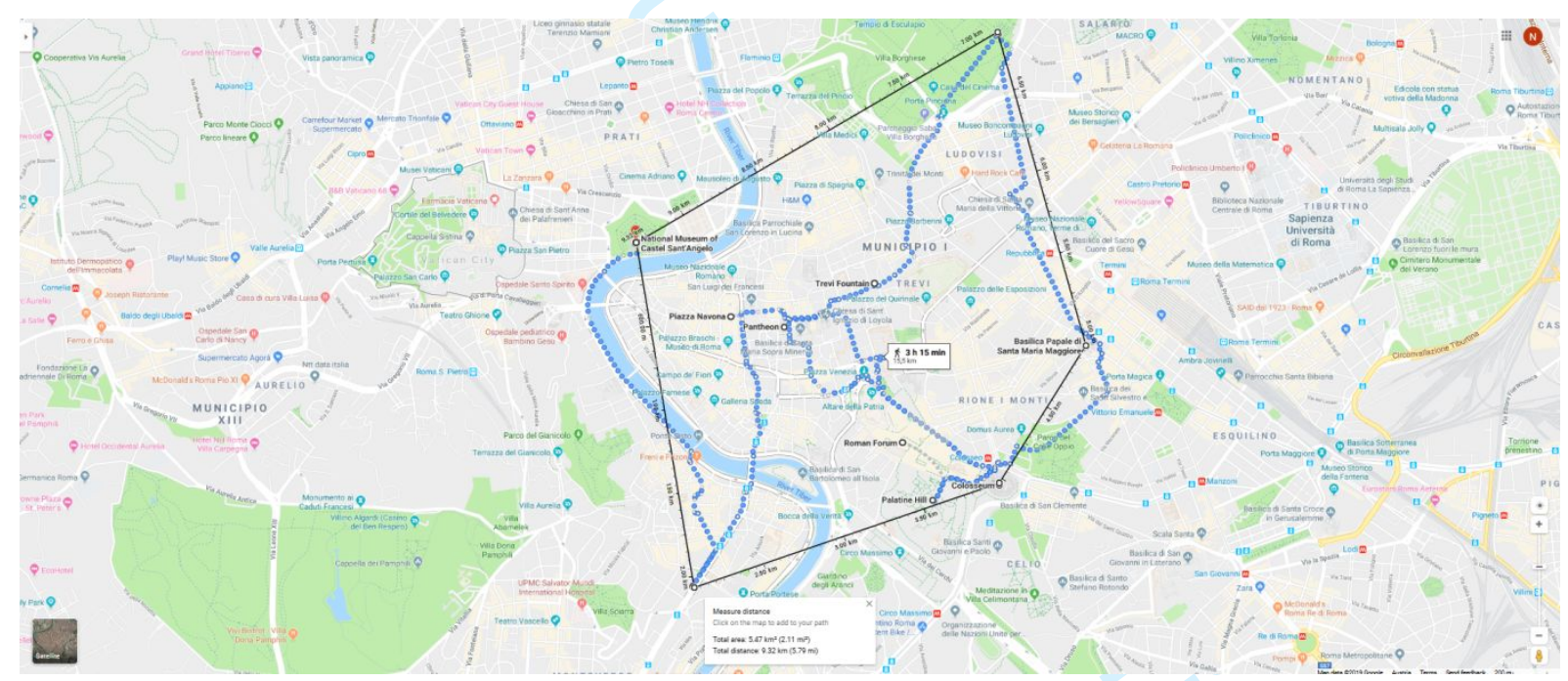


Seville $=1.9$ square kilometre

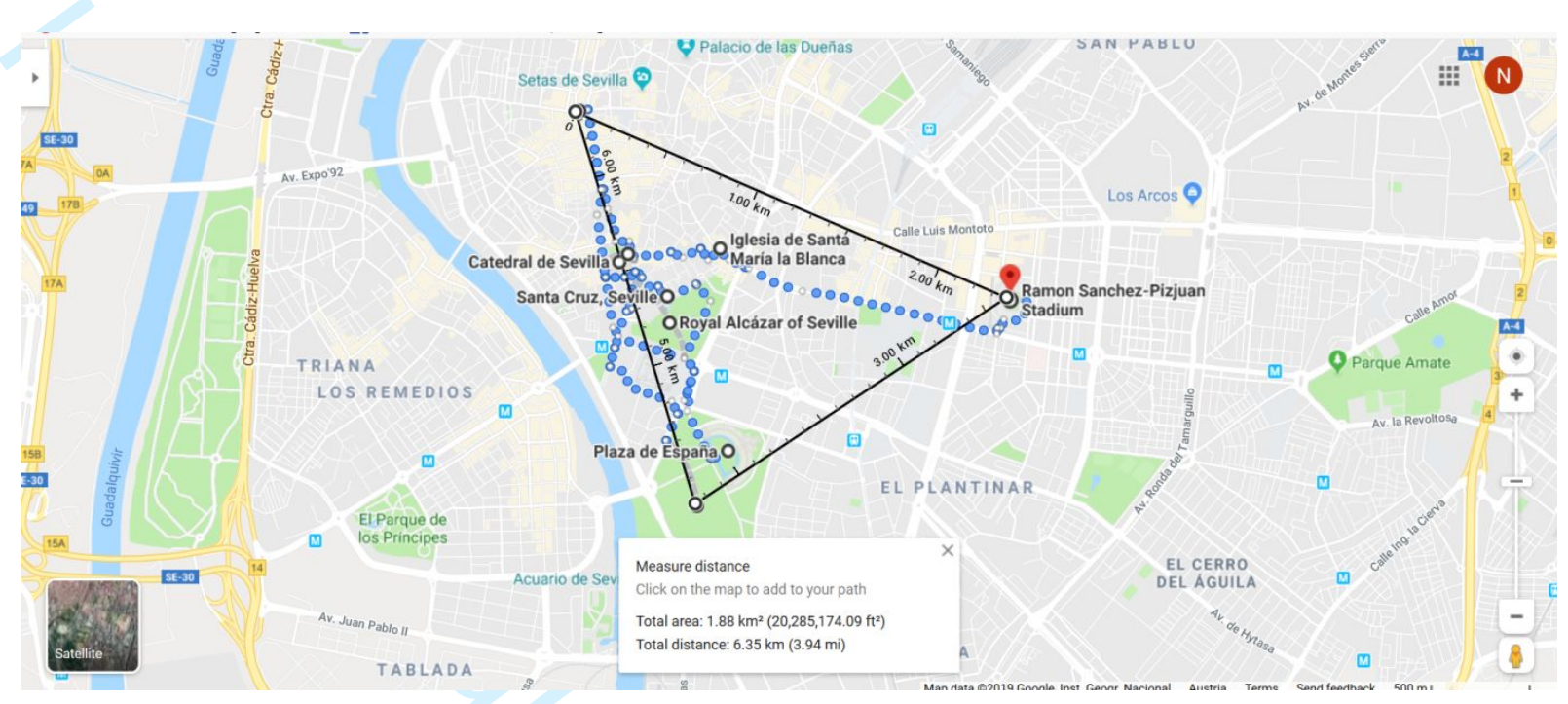

Venice $=6.3$ square kilometre

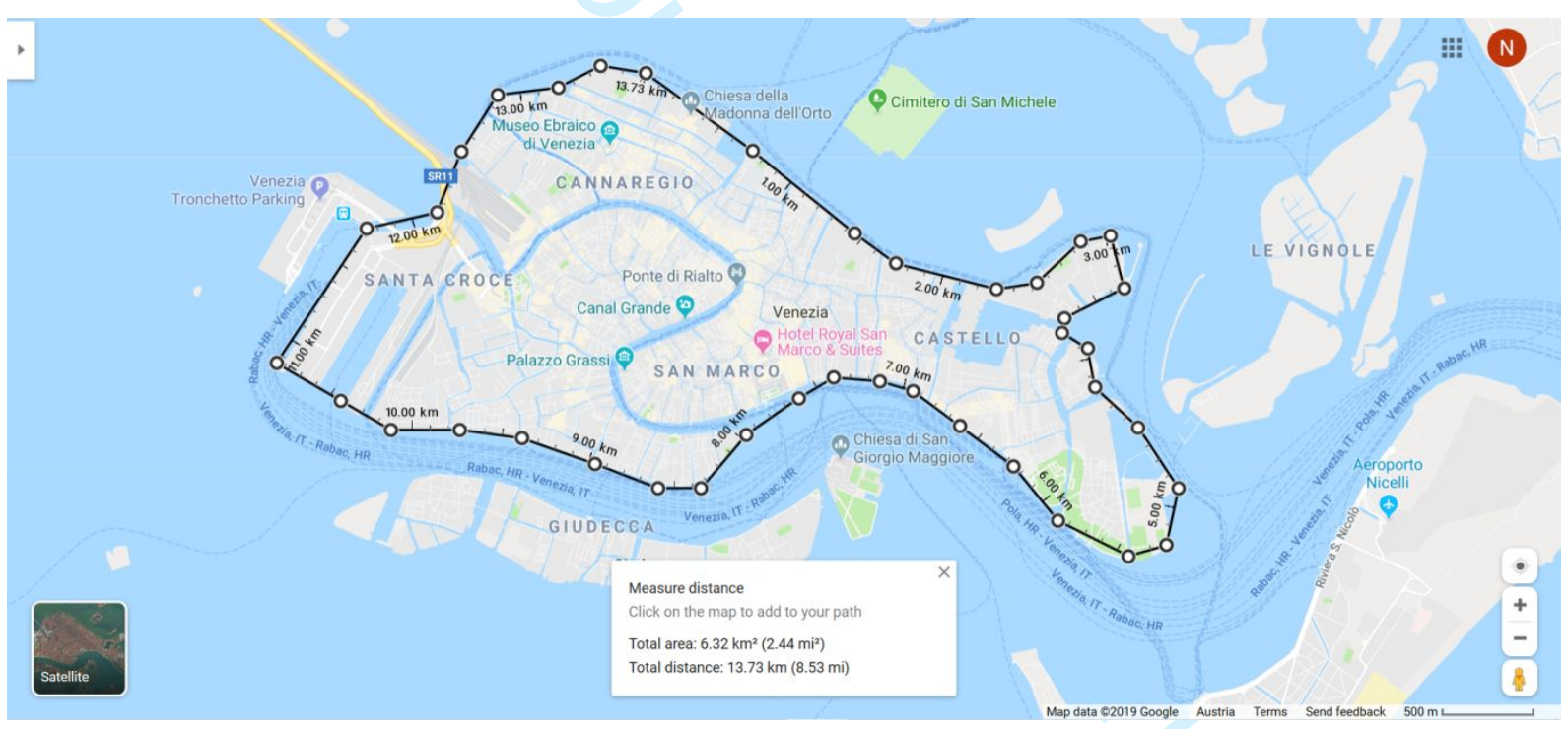


Vienna $=6.4$ square kilometre

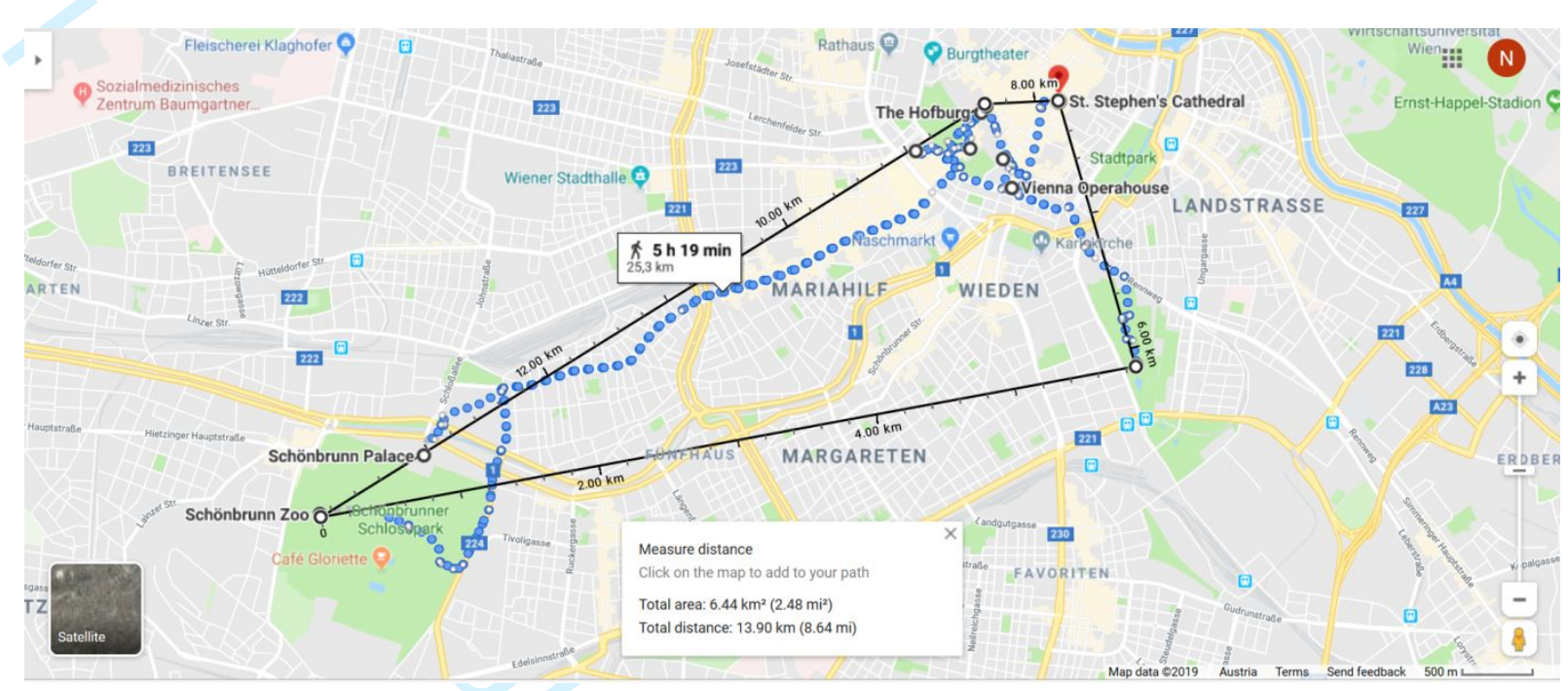

